\title{
Neuronal Kmt2a/Mll1 Histone Methyltransferase Is Essential for Prefrontal Synaptic Plasticity and Working Memory
}

\author{
Mira Jakovcevski, ${ }^{1,6 *}$ Hongyu Ruan, ${ }^{3 \star}$ Erica Y. Shen, ${ }^{1 \star}$ () Aslihan Dincer, ${ }^{1,2 *}$ Behnam Javidfar, ${ }^{1}$ Qi Ma, ${ }^{2}$ @Cyril J. Peter, ${ }^{1}$ \\ Iris Cheung, ${ }^{4}$ Amanda C. Mitchell, ${ }^{3}$ Yan Jiang, ${ }^{1}$ Cong L. Lin, ${ }^{1}$ Venu Pothula, ${ }^{1}$ A. Francis Stewart, ${ }^{7}$ Patricia Ernst,${ }^{5}$ \\ Wei-Dong Yao, ${ }^{3}$ and Schahram Akbarian ${ }^{1,4}$ \\ ${ }^{1}$ Department of Psychiatry and Friedman Brain Institute and ${ }^{2}$ Department of Genetics and Genomics Science and Institute for Multiscale Biology, Icahn \\ School of Medicine at Mount Sinai, New York, New York 10029, ${ }^{3}$ New England Primate Center, Harvard Medical School, Southborough, Massachusetts \\ 01702, ${ }^{4}$ Brudnick Neuropsychiatric Research Institute, University of Massachusetts Medical School, Worcester, Massachusetts 01604, ${ }^{5}$ Department of \\ Genetics and Department of Microbiology and Immunology, Norris Cotton Cancer Center, Geisel School of Medicine at Dartmouth, Hanover New \\ Hampshire 03755, ${ }^{6}$ Max Planck Institute of Psychiatry, 80804 Munich, Germany, and ${ }^{7}$ Genomics BioinnovationsZentrum, Technische Universitaet, 01307 \\ Dresden, Germany
}

Neuronal histone H3-lysine 4 methylation landscapes are defined by sharp peaks at gene promoters and other cis-regulatory sequences, but molecular and cellular phenotypes after neuron-specific deletion of H3K4 methyl-regulators remain largely unexplored. We report that neuronal ablation of the H3K4-specific methyltransferase, Kmt2a/Mixed-lineage leukemia 1 (Mll1), in mouse postnatal forebrain and adult prefrontal cortex (PFC) is associated with increased anxiety and robust cognitive deficits without locomotor dysfunction. In contrast, only mild behavioral phenotypes were observed after ablation of the Mll1 ortholog Kmt2b/Mll2 in PFC. Impaired working memory after Kmt2a/Mll1 ablation in PFC neurons was associated with loss of training-induced transient waves of Arc immediate early gene expression critical for synaptic plasticity. Medial prefrontal layer $V$ pyramidal neurons, a major output relay of the cortex, demonstrated severely impaired synaptic facilitation and temporal summation, two forms of short-term plasticity essential for working memory. Chromatin immunoprecipitation followed by deep sequencing in Mll1-deficient cortical neurons revealed downregulated expression and loss of the transcriptional mark, trimethyl-H3K4, at $<50$ loci, including the homeodomain transcription factor Meis2. Small RNAmediated Meis2 knockdown in PFC was associated with working memory defects similar to those elicited by Mll1 deletion. Therefore, mature prefrontal neurons critically depend on maintenance of Mll1-regulated H3K4 methylation at a subset of genes with an essential role in cognition and emotion.

Key words: ChIP-seq; histone H3-lysine 4 methylation; neuroepigenetics; neuronal nuclei sorting; short-term plasticity; working memory

\section{Introduction}

Neuronal health and function critically depends on proper regulation of the epigenome, with various DNA methyl-cytosine derivatives and a large number of post-translational histone modifications (Houston et al., 2013; Fischer, 2014; LopezAtalaya and Barco, 2014; Schoch and Abel, 2014). For example,

\footnotetext{
Received July 17, 2014; revised Feb. 4, 2015; accepted Feb. 9, 2015

Author contributions: W.-D.Y. and S.A. designed research; M.J., H.R., E.Y.S., Q.M., C.J.P., Y.J., I.C., C.L.L., A.C.M., B.J., and V.P. performed research;P.E. and A.F.S. contributed unpublished reagents/analytic tools; M.J., H.R., E.Y.S., A.D., and W.-D.Y. analyzed data; M.J., W.-D.Y., and S.A. wrote the paper.

This work was supported by National Institutes of Health grants P50MH096890 and R01MH086509 (to S.A.) and OD011103 and R01DA032283 (to W.-D.Y.) and by a Marie Curie Intra European Fellowship within the seventh European Community Framework Programme (to M.J.). We thank Yin Guo and Lily C. Lin for technical assistance and Jan Deussing for providing resources.

*M.J., H.R., E.Y.S., and A.D. contributed equally to this work.

The authors declare no competing financial interests.

Correspondence should be addressed to either of the following: Schahram Akbarian, Department of Psychiatry and Friedman Brain Institute, Icahn School of Medicine at Mount Sinai, New York, NY 10029, E-mail: Schahram.akbarian@mssm.edu; or Wei-Dong Yao, New England Primate Center, Harvard Medical School, Southborough, MA 01702.E-mail: yaow@upstate.edu.

DOI:10.1523/JNEUROSCI.3004-14.2015

Copyright $\odot 2015$ the authors $\quad 0270-6474 / 15 / 355097-12 \$ 15.00 / 0$
}

methylation of histone H3-lysine 4, including the trimethylated form (H3K4me3) — sharply enriched at gene-proximal promoters and transcription start sites (TSS; Guenther et al., 2007; Barrera et al., 2008)—is highly regulated throughout all periods of development and aging in the human and nonhuman primate cerebral cortex (Cheung et al., 2010; Han et al., 2012), and altered in a locus-specific manner in cortical neurons of subjects diagnosed with neuropsychiatric (Huang et al., 2007; Shulha et al., 2012) or neurodegenerative (Bai et al., 2015) disease. Furthermore, mutations in at least six human genes encoding $\mathrm{H} 3 \mathrm{~K} 4$ specific demethylases or methyltransferases (KDM5A, KDM5C, $K M T 2 A, K M T 2 C, K M T 2 D$, and KMT2F) have been linked to various neurodevelopmental disorders and syndromes (Shen et al., 2014; Takata et al., 2014). It is surprising, however, that only very little is known about the role of these disease-relevant regulators of $\mathrm{H} 3 \mathrm{~K} 4$ methylation in mature cortical neurons, with many of the mouse models studied to date confined to mutagenesis in the germline (Kim et al., 2007; Gupta et al., 2010), or the developing early postnatal brain and adult hippocampus (Kerimoglu et al., 2013), or focused on transient knockdown in subcortical structures (Aguilar-Valles et al., 2014). 
Here, we show that Kmt2a methyltransferase, also known as Mll1, is an essential regulator of complex behaviors, by preserving - in neurons of the adult PFC - proper levels of H3K4me3 at a small, but critical, subset of gene promoters important for cognition and emotion. Our study includes a very deep and integrative analysis, with neuron-specific Mll1 ablations and small RNA-mediated knockdown assays of Mll1 target genes at different developmental stages (including adult). These are complemented by cell typespecific genome-scale mapping of $\mathrm{H} 3 \mathrm{~K} 4 \mathrm{me} 3$ landscapes at single base pair resolution in conjunction with transcriptome analysis, slice recordings of prefrontal projection neurons, and a range of behavioral assays with information about PFCregulated cognition and emotion, including working memory and anxiety.

\section{Materials and Methods Animals}

All animal experiments were approved by the Animal Use and Care committee of the participating institutions. Mice were kept under specific pathogen-free constant conditions $\left(21 \pm 1^{\circ} \mathrm{C} ; 60 \%\right.$ humidity $)$ and mice of both sexes were used for the experiments, with each mutant mouse matched to a control mouse of the same gender. Food and water was supplied ad libitum in an animal facility with a regular $12 \mathrm{~h} \mathrm{light/dark}$ cycle (light on at 7:00 A.M.). All experiments were in accordance with the guidelines of the Institutional Animal Care and Use Committee of the participating institutions.

\section{Cell- and region-specific mutagenesis}

All mouse lines had been backcrossed to the C57BL/6J background for at least eight generations before this study. Conditional deletion of Mll1 was obtained by breeding a previously described Mll12lox/2lox allele (Jude et al., 2007) with a CaMKII $\alpha$-Cre (CamK-Cre) transgenic line that recombines in forebrain neurons starting at the time of birth, resulting in widespread Cre-mediated deletion in the forebrain before P18 (Akbarian et al., 2002). In addition, an independent set of adult $M l l 1^{2 l o x / 2 l o x}$ mice, and previously described Mll2 2 lox/2lox animals (Glaser et al., 2009; Kerimoglu et al., 2013), were subjected to Cre-mediated deletion in the rostromedial cortex, as described in the following paragraph.

Stereotactic delivery of adeno-associated virus, serotype 8 (AAV) for expression of a CreGFP fusion protein under control of the neuronspecific SYNAPSIN1 promoter, or of Accell siRNAs (DPharmacon; Nakajima et al., 2012), was done as follows: mice were anesthetized with a ketamine/xylazine mixture (100 and $15 \mathrm{mg} / \mathrm{kg}$, i.p.; Sigma-Aldrich) and $1 \mu \mathrm{l}$ of virus for each hemisphere $\left(\sim 4.7 \times 10^{9}\right.$ genomic copies $)$ or siRNA $(2 \mu \mathrm{g} / \mu \mathrm{l}$ in delivery medium; GE Healthcare) was injected at a rate of $0.25 \mu \mathrm{l} / \mathrm{min}$ using a Hamilton syringe, a micro pump, and stereotactic frame (Stoelting). Coordinates for injection were as follows: $+1.5 \mathrm{~mm}$ anterior/posterior, $\pm 0.4 \mathrm{~mm}$ medial/lateral, and $-1.5 \mathrm{~mm}$ dorsal/ventral. All experiments were performed at least 3-4 weeks (AAV-Cre) or $3 \mathrm{~d}$ (siRNA) after surgery.

\section{Behavioral studies \\ Spatial working memory}

T-maze. The maze consisted of three equally sized arms $(30 \times 10 \mathrm{~cm}, 30$ $\mathrm{cm}$ high) made from white plastic: one start arm leading in a $90^{\circ}$ angle to the two target arms (opposing each other). All arms were equipped with sliding doors. During the test mice were first confined in the start arm. Once the door of this arm was opened the mouse was allowed to choose one of the target arms. The door of the opposing target arm was closed until the mouse returned to the start arm. The protocol was repeated until the mouse had made 15 choices. To analyze the working memory performance, the animal's alternations between the target arms were calculated as the percentage of the total number of possible (ad maximum) alternations (i.e., 14) for each mouse. The test was administered daily for a period of $4 \mathrm{~d}$.

Eight-arm radial maze. The apparatus consisted of eight arms $(7.5 \times$ $35 \mathrm{~cm}, 17.5 \mathrm{~cm}$ high walls), which were assembled in a radial manner around a circular starting platform. Mice were placed onto the starting platform and were free to enter the arms. The test was continued until all eight arms had been visited once. Each repeat entry in an arm previously visited is counted as a "mistake."

\section{Anxiety}

Light-dark box. An open field apparatus as described below and with the same illumination was used for this test. Additionally, a black plastic box $(10 \times 10 \mathrm{~cm}, 25 \mathrm{~cm}$ high) was introduced into the apparatus. The box was equipped with a black plastic lid and had an opening on the bottom ( $5 \mathrm{~cm}$ diameter) to allow the mouse to enter into the surrounding arena. Mice were placed into the black box, the lid was closed, and mice were allowed to move freely in the entire apparatus for $10 \mathrm{~min}$. Behavior was video recorded. The latency to enter into the light compartment for the first time and transitions between the two compartments were analyzed by a trained observer.

Open field. The apparatus consisted of a white Plexiglas box $(40 \times 40$ $\mathrm{cm}, 40 \mathrm{~cm}$ high), illuminated with bright white light ( $350 \mathrm{lux}$ ). Mice were placed individually into the box for $15 \mathrm{~min}$. Time spent in an imaginary center square of the open field $(15 \times 15 \mathrm{~cm})$ was recorded using the video-based EthoVision tracking system (Noldus).

Nest-building behavior. Mice received a fresh nestlet (Ancare) and a new standard housing cage with fresh bedding $1 \mathrm{~h}$ before the beginning of the dark phase. Nest status was assessed at the end of the dark phase. Nests were scored according to categories similar to a previously described protocol (Deacon, 2006): untouched nestlet (0 points), partially shredded nestlet ( 1 point), shredded nestlet with beginning of a nest-like structure ( 2 points), full cup-like nest ( 3 points), and round enclosure (4 points).

Motor skills/rotarod. Rotarod (Ugo Basile) was used to measure motor coordination in mice. The rotarod was set up with a slow acceleration mode, in which the rotation speed is accelerated from 2 to $40 \mathrm{rpm}$ in 5 $\mathrm{min}$. Mice were subjected to 10 consecutive $5 \mathrm{~min}$ trials with a $5 \mathrm{~min}$ intertrial interval. Twenty-four hours later, mice were retested for three consecutive trials (at 5 min intervals), and locomotor coordination performance was defined as the mean latency to fall off.

\section{Electrophysiology}

Detailed methods for slice preparation and electrophysiological recordings were described previously (Xu et al., 2009). Whole-cell patch-clamp recordings were performed on individual layer $\mathrm{V}$ pyramidal neurons under infrared differential interference contrast microscopy using an Axoclamp 2B or a Multiclamp 700B amplifier (Molecular Devices). Pyramidal neurons were identified by their morphology. When necessary, presynaptic stimuli $(200 \mu \mathrm{s})$ were delivered with a concentric bipolar electrode (FHC) placed at layer II/III. All recordings were done at $32^{\circ} \mathrm{C}$ with a temperature controller (Warner Instruments). For voltage-clamp experiments, cells were held at $-60 \mathrm{mV}$, unless specified otherwise. For pair-pulse ratio (PPR) measurements, a pair of EPSCs was evoked by a pair of pulses $(0.033 \mathrm{~Hz})$ with varying interstimulus intervals (ISIs). Responses from 5 to 7 pairs of the same ISI were averaged to obtain the PPR at the ISI. For mEPSCs, tetrodotoxin ( $1 \mu \mathrm{M}$; Sigma-Aldrich) and AP-5 ( $50 \mu \mathrm{M}$; Abcam Biochemicals) were added to block voltage-gated sodium channels and NMDA receptors, respectively. For current-clamp experiments, presynaptically evoked EPSPs were recorded from neurons at their native resting potentials. For temporal synaptic summation assays, a train of 15 pulses with varying frequencies was delivered every $1 \mathrm{~min}$. Responses from 3 to 5 train stimulations of the same frequency were averaged to calculate the summation for the frequency. For synaptic augmentation and post-tetanus potential (PTP) assays, a pulse train of $0.5 \mathrm{~Hz}$, with $10 \mathrm{~Hz} 15$ pulse tetanus replacing the sixth pulse, was delivered every $5 \mathrm{~min}$.

\section{Immunoblotting and histology}

Frontal cortices were directly homogenized in $500 \mu \mathrm{l} 0.025 \mathrm{M} \mathrm{Tris-HCl}$, $\mathrm{pH} 7.5$, supplemented with protease inhibitor cocktail (Roche) using a rotor stator (Qiagen). All homogenates were lysed in RIPA buffer for 30 $\min$ at $4^{\circ} \mathrm{C}$. Samples were boiled in Laemmli buffer under denaturizing conditions, under addition of SDS and $\beta$-mercaptoethanol, for $10 \mathrm{~min}$ at 
$100^{\circ} \mathrm{C}$. Samples were run on $4-20 \%$ Tris $\mathrm{HCl}$ gradient gels and blotted onto nitrocellulose membranes. The following antibodies were used: mouse monoclonal anti-Mll1 N terminus (1:1000; Millipore or 1:1000; Bethyl Laboratories) and mouse monoclonal anti- $\beta$-actin (1:20,000; Sigma-Aldrich). Appropriate HRP-conjugated secondary antibodies (Invitrogen/Life Technologies) were used and signals developed with chemiluminescence reagents (Pierce) and captured on $\mathrm{x}$-ray film (Kodak). Labeled bands were densitometrically analyzed using the software Quantity One (Bio-Rad). For immunohistochemistry, Mll1 mutant and control mice were killed and their brains were collected and rapidly frozen over dry ice and stored at $-80^{\circ} \mathrm{C}$. Sagittal sections $(20 \mu \mathrm{m})$ were cut on a Leica cryostat and thaw mounted onto slides. Sections were incubated with Alexa Fluor 555-conjugated primary antibodies against NeuN (1:1000; EMD Millipore). Sections were coverslipped using Vectashield mounting media with DAPI (Vector Laboratories). Images were taken using a Zeiss confocal microscope. For Nissl staining, Mll1 mutant and control mouse brain sections were dehydrated in ethanol, rehydrated, and stained in $0.1 \%$ crystal violet acetate for $10 \mathrm{~min}$. Sections were then rinsed in distilled water, then in 70 and $95 \%$ ethanol, followed by incubation in chloroform for $20 \mathrm{~min}$ and differentiation in $95 \%$ ethanol with acetic acid. Finally, sections were rinsed with $100 \%$ ethanol, then cleared in $100 \%$ xylene and overslipped with xylene-based mounting media.

\section{Genomics}

Transcriptome profiling. RNA from the rostromedial portion of the frontal cortex of 10- to 12-week-old conditional CamK-Cre Mll1 mutant and control mice, including the prelimbic and cingulate areas, was isolated using an RNeasy Lipid Tissue kit (Qiagen) in conjunction with column DNase I (Qiagen) treatment to remove contaminating DNA. RNA integrity was assessed by chip-based capillary electrophoreses using the RNA 6000 Nano Chip on the Bioanalyzer (Agilent Technologies). Only samples with an RIN $>9$ were included in the study and transcribed into single-stranded cDNA using the Ambion WT Expression Kit (Life technologies). Samples were hybridized onto one GeneChip Mouse Gene 1.0 ST Array (Affymetrix), each, using a hybridization mix [100 mM MES, $1 \mathrm{M}\left(\mathrm{Na}^{+}\right), 20 \mathrm{~mm}$ EDTA, $0.01 \%$ Tween 20 ; containing $1 \mu \mathrm{l}$ of BSA (50 $\mathrm{mg} / \mathrm{ml}$ ) and $1 \mu \mathrm{l}$ of $10 \mathrm{mg} / \mathrm{ml}$ Herring Sperm DNA per $100 \mu \mathrm{l}$ for $16 \mathrm{~h}$. Chips underwent multiple rounds of automated washing, were stained, and finally scanned with the Affymetrix GeneChip Scanner 3000 7G. Quality of microarray data was assessed using the Bioconductor package, array Quality Metrics (Kauffmann et al., 2009). Microarray data were then uploaded to the Microarray Computational Environment 2.0 (MACE), which employs Robust Multi-array Average to preprocess raw oligonucleotide microarray data. The preprocessed data were stored as base $2 \log$ transformed real signal numbers and used for fold-change calculations and statistical tests. Mean signal values and SDs were first computed for each gene across samples and the fold change (FC) of expression of a gene between treatment groups was calculated by taking the ratio of these mean signal values. To determine differential expression of genes MACE internally conducts a Student's $t$ test with the expression signal values of the two hybridizations for all genes in the set. Parameters for significance were either FC $\geq 1.5(p \leq 0.05)$ or $\mathrm{FC} \geq 1.2(p \leq 0.05)$. The pool of genes with $\mathrm{FC} \geq 1.2(p \leq 0.05)$ was used to generate a heat map and to perform single-linkage clustering analysis.

Nuclei sorting and ChIP-seq. For fluorescence-activated nuclei sorting, nuclei were extracted from cerebral cortex in hypotonic lysis solution, purified by centrifugation, and then resuspended in $1 \mathrm{ml}$ PBS containing $0.72 \%$ normal goat serum, $0.036 \%$ BSA, 1:1200 anti-NeuN (monoclonal mouse; Millipore), and 1:1400 Alexa Fluor 488 goat anti-mouse secondary antibody (Invitrogen/Life Technologies). Samples were incubated for at least $45 \mathrm{~min}$ by rotating in the dark at $4^{\circ} \mathrm{C}$. A small fraction of the nuclei was used to control for background from the secondary antibody (i.e., unstained control where anti-NeuN was omitted). Sorting was done on a FACSVantage SE flow cytometer. Nuclei were pelleted and then diluted in MNase digestion/nuclei permeabilization buffer (10 mM Tris, $\mathrm{pH} 7.5$; $4 \mathrm{~mm} \mathrm{MgCl}^{2}$; and $1 \mathrm{~mm} \mathrm{Ca}^{2+}$ ).
To prepare the chromatin for chromatin immunoprecipitation (ChIP), samples were prewarmed to $37^{\circ} \mathrm{C}$ for $2 \mathrm{~min}$, MNase $(4 \mu \mathrm{l}$ of 0.4 $\mathrm{U} / \mu \mathrm{l})$ was added, and the samples were incubated for $5 \mathrm{~min}$ at $37^{\circ} \mathrm{C}$ to obtain mononucleosomal DNA. Reaction was stopped with $0.5 \mathrm{~m}$ EDTA, $\mathrm{pH}$ 8. Nuclei were swollen to release chromatin after addition of hypotonization buffer (0.2 mM EDTA, pH 8, containing PMSF, DTT, and benzamidine). After samples were precleared with protein $G$ agarose slurry, anti H3K4me3 antibody (rabbit polyclonal; Millipore) and ChIP dilution buffer (50 mM EDTA, $200 \mathrm{~mm}$ Tris, and $500 \mathrm{~mm} \mathrm{NaCl}$ ) were added and samples incubated for $16 \mathrm{~h}$ at $4^{\circ} \mathrm{C}$ under rotation. Then, the DNA-protein-antibody complexes were captured with protein $\mathrm{G}$ agarose slurry under rotation. Agarose beads were washed several times (low-salt buffer, high-salt buffer, lithium chloride, and TE buffer as described; Matevossian and Akbarian, 2008). Complexes were eluted from the beads, and proteins digested with Proteinase K. DNA was purified by phenol-chloroform extraction.

ChIP DNA was end repaired (End-it DNA Repair kit; Epicentre) and A tailed (Klenow Exo-minus; Epicentre). Adaptors (Genomic Adaptor Oligo Mix; Illumina) were ligated to the ChIP-DNA (Fast-Link kit; Epicentre) and libraries were then PCR amplified and PCR products were gel extracted. The region of 200-300 bps was cut out of the gel, containing a library of expected size, consisting of the $150 \mathrm{bp}$ mononucleosomal ChIP-DNA plus 100 bp adaptors. Between each step the samples were cleaned with column-based PCR purification kits (Qiagen). Libraries were run on a Bioanalyzer to determine concentration and size distribution of the library. Libraries were sequenced with the Genome Analyzer II (Illumina). All sequencing libraries contained single-end $36 \mathrm{bp}$ raw reads and were mapped to the July 2007 assembly of the mouse genome (UCSC version mm9, NCBI37) using Bowtie (version 0.12.8; Langmead et al., 2009), thereby keeping for further analyses only reads that mapped uniquely to the genome with at most two mismatches at the first 36 bases. A total of four Camk-Cre ${ }^{+}, \mathrm{Mll1}^{\text {flox/flox }}$ and four age-matched postweanling and young adult gender-matched $(2 \mathrm{M} / 2 \mathrm{~F})$ controls (Camk-Cre ${ }^{-}$, Mll flox/flox $)$ were used for H3K4me3 ChIP-seq, using sorted cortical $\mathrm{NeuN}^{+}$nuclei as input material. The number of unique reads (mean \pm SEM, control $1671 \times 10^{8} \pm 0.191 \times 10^{8}$; mutant $1254 \times 10^{8} \pm 0.270 \times$ $10^{8}$ ) and the unique sequence alignment fraction ( $\mathrm{mm} 9$ genome, control $97.63 \pm 0.46 \%$; mutant $97.62 \pm 0.32 \%$ ) were very similar between genotype, without significant differences.

Since the binding of $\mathrm{H} 3 \mathrm{~K} 4 \mathrm{me} 3$ has far wider distribution than that of transcription factors, we ensured maximum sequencing depth by pooling the reads for analysis. To this end, we called peaks from pooled reads (four wild-type H3K4me3 datasets were pooled for wild-type condition and four Mll1 mutant H3K4me3 datasets were pooled for Mll1 mutant condition). The number of uniquely mapped reads in $\mathrm{H} 3 \mathrm{~K} 4 \mathrm{me} 3$ was 60.8 million for four pooled wild-type mouse ChIP-seq datasets and 50.1 million for four pooled Mll1 mutant mouse datasets. Peaks significantly enriched for ChIP-seq reads were identified by using model-based analysis for ChIP-seq (Zhang et al., 2008; version 2.0.10.20120913) with default settings except: - no model - shiftsize $=110$ with an FDR significance threshold of $0.01-$ qvalue $=1 \mathrm{e}-2$. Distribution of enrichment peaks in the distal promoters $(>10 \mathrm{~kb}$ from a transcription start site, or TSS) and proximal promoters (up to $+5 \mathrm{~kb}$ from TSS) was calculated. All histone ChIP-seq data were normalized using the MAnorm: a robust model for quantitative comparison of ChIP-seq datasets (Shao et al., 2012), which allows for quantitative comparison between wild-type and knock-out-specific ChIP-seq peaks. Basically, "MAnorm" normalization (Shao et al., 2012) first assumes that the true intensities of most common peaks are the same between two ChIP-seq samples. This assumption is valid when the binding regions represented by the common peaks show a much higher level of colocalization between samples than that expected at random, and thus binding at the common peaks should be determined by similar mechanisms and exhibit similar global binding intensity between samples. Second, the observed differences in sequence read density in common peaks are presumed to reflect the scaling relationship of ChIP-seq signals between two samples, which can thus be applied to all peaks. Based on these hypotheses, the $\log 2$ ratio of read density between two samples $M=\log 2$ (read density in Mll1 mutant sample/read density in wild-type sample) was plotted against the average 
$\log 2$ read density $A=0.5 \times \log 2$ (read density in Mll1 mutant sample $\times$ read density in wild-type sample) for all peaks to identify and categorize Mll1 mutant-specific, wild-type-specific, and common peaks. Identified peaks were then mapped to the nearest Refseq annotated genes (Pruitt et al., 2012) for downstream analyses. $P$ values were calculated for each peak to describe the statistical significance of read-intensity difference between samples being compared based on a Bayesian model (Audic and Claverie, 1997).

\section{RNA quantification}

RNA was transcribed into cDNA using SuperScript III (Invitrogen) and random hexamer primers. cDNA was thereafter amplified on a Roche 2.0, 96 or 480 light cycler using SYBR Green PCR Master Mix kits (Qiagen/Roche). Primer pairs were designed using Primer Blast, Primer Express, or Primer 3. Data were normalized by housekeeping transcript hypoxanthine-guanine phosphoribosyltransferase (Hprt) and/or $18 \mathrm{~s}$ as endogenous reference. The following primers were used: Mll1 deletion primer (forward) Fwd 5'-TAA TCCTAGCCGTTAGGCCG-3' and (reverse) Rev 5' -TTGGGGCAGGTTTGGGTTAG-3', Mll2 primer Fwd 5' TGCAAAGTGTGCCAATCGTG-3' and Rev 5'-GACAGCGGTGAC AGAGTGAA-3', Mll2 deletion primer Fwd 5'-CATCTTCCCTG ACCCACCAC- $3^{\prime}$ and Rev $5^{\prime}$-CTCCCCTGA GGTAGGTGTGA-3' ${ }^{\prime}$, Mll3 Fwd $5^{\prime}$-CAAAGAACAATCTGTGGAAGAGGA- $3^{\prime}$ and Rev $5^{\prime}$-TGGCTTCTACGCCAACAGAG-3', Meis2 Fwd 5' -TTGGCGGACAGG TTATGGAC- ${ }^{\prime}$ and Rev 5' ${ }^{\prime}$-TGCGTGTGTTTCCTTCTTCCT-3', Satb2 Fwd 5'-CAAGAGTGGCAT TCAACCGC-3' and Rev 5'-ACGCAGTCCTGGGATCTTCT-3', Arc Fwd 5'-CCCAGC AGT GATTCATACCA GT-3' and Rev 5'-ACCCATGTAGGCAGCTTCAG-3', Hprt Fwd 5'-G TT CTTTGCTGACCTGCTGGA-3' and $5^{\prime}$-TCCCCCGTTGACTG ATCATT- ${ }^{\prime}$, and $18 s$ Fwd $5^{\prime}$-CATGGCCGTTCTTAGTTGGT- $3^{\prime}$ and Rev $5^{\prime}$-GAACGCCACTTGTCCCTCTA-3'. Hprt and $18 \mathrm{~s}$ transcripts were used for normalization. For graphical presentation and statistical analysis, the mRNA level for each sample was expressed as percentage of the mean value of the respective control group.

\section{ChIP-PCR}

Mouse cortex samples were directly dounced in $500 \mu \mathrm{l}$ MNase digestion/ nuclei permeabilization buffer (10 mm Tris, $\mathrm{pH} 7.5 ; 4 \mathrm{~mm} \mathrm{MgCl}^{2}$; and $\left.1 \mathrm{mM} \mathrm{Ca}^{2+}\right)$. Homogenates were then prewarmed to $37^{\circ} \mathrm{C}$ for $2 \mathrm{~min}$, MNase ( $7 \mu \mathrm{l}$ of $0.4 \mathrm{U} / \mu \mathrm{l})$ was added, and the samples were incubated for an additional $10 \mathrm{~min}$ at $37^{\circ} \mathrm{C}$. Samples were incubated in $5 \mathrm{ml}$ hypotonization buffer for $1 \mathrm{~h}$ with intermittent vortexing. Cell debris was removed by centrifugation $\left(3000 \mathrm{rpm}\right.$, at $4^{\circ} \mathrm{C}$ for $10 \mathrm{~min}$ ) in a swing bucket centrifuge. Then $1600 \mu \mathrm{l}$ of the supernatant was used for each ChIP reaction, supplemented with ChIP dilution buffer (50 mM EDTA, 200 $\mathrm{mm}$ Tris, and $500 \mathrm{~mm} \mathrm{NaCl}$ ), and $3 \mu \mathrm{l}$ of one of the following polyclonal rabbit antibodies: anti H3K4me1 antibody (Abcam), anti H3K27ac antibody (Cell Signaling Technology), and anti H3K27me3 (Millipore). After incubation for $16 \mathrm{~h}$ under rotation, the DNA-protein-antibody complexes were captured with protein $\mathrm{G}$ magnetic beads (Millipore) for $2 \mathrm{~h}$ under rotation. Beads were washed once each with low-salt buffer, high-salt buffer, lithium chloride, and TE buffer. DNA-protein-antibody complexes were eluted at $65^{\circ} \mathrm{C}$ for $30 \mathrm{~min}$ under shaking at $1400 \mathrm{rpm}$, proteins were digested with proteinase $\mathrm{K}$ for $3 \mathrm{~h}$, and ChIP-DNA was eluted using a QIAquick PCR purification kit (Qiagen). DNA from 200 $\mu \mathrm{l}$ of each input sample was extracted in parallel. For quantification by qPCR ChIP-DNA was diluted 1:5 and input DNA was diluted 1:20 with elution buffer (Qiagen). PCRs ( $10 \mu$ l final volume) were performed using QuantiFast SYBR Green PCR Master Mix, specific primers at a final concentration of $1.5 \mu \mathrm{M}$, and $2 \mu \mathrm{l}$ of ChIP-DNA or input per reaction on a LightCycler 2.0 (Roche Diagnostics). PCRs were run in duplicates. Ct values for the target H3K4me3-enriched sequences of Meis2 (Fwd 5' CGAGAGCAGCATTCAGGGAA- ${ }^{\prime}$ and Rev $5^{\prime}$-ACTCCACTT CTCCC TGGGTT-3' to amplify mm9 chromosome 2, base pair 115,889,618$115,889,483$, in close proximity to the transcription start site of Meis2, chr2 bp 115,890,794) and H3K4me1-enriched sequences (Fwd 5'CTCAGGCGGTATAAGCAGCA-3' and Rev $5^{\prime}$-TGGAGAGCCTGCG TAAATCC-3 to amplify mm9 chromosome 2, base pair $115,835,108-$ $115,834,987$ ) were normalized by the housekeeping gene B2m (Fwd 5' -
GGGAAA GTCCCTTTGTAACCT-3' and Rev 5'-GCGCGCGCTC TTATATAGTT-3') and by the input Ct value. Expression levels are presented relative to the wild-type levels set to 1 .

All behavioral, molecular, and electrophysiological data were expressed as mean \pm SEM and significance of group differences evaluated by $t$ test or, when indicated, by ANOVA.

\section{Results}

A Camk2a-Cre transgene was bred into a line of mice carrying a conditional Mll1 allele, with loxP sites flanking exons 3 and 4 (Jude et al., 2007). Mll1 encodes a large, up to 3966 aa protein, which is processed by post-translational cleavage into multiple smaller fragments. Among these, an N-terminal $\sim 320 \mathrm{kDa}$ fragment and a C-terminal $\sim 180 \mathrm{kDa}$ fragment subsequently reassemble into a catalytically active postcleavage complex (Hsieh et al., 2003). Immunoblotting of nuclear versus cytoplasm (nonnuclear) confirmed that the protein is enriched in the cell nucleus (Fig. 1A). Furthermore, Camk-Cre ${ }^{+}, \mathrm{Mll1}^{2 l o x / 2 l o x}$ mice showed a strong reduction of the $\sim 320 \mathrm{kDa}$ N-MLL1 immunoreactivity in adult mutant cortex, and to some extent also in P8 cortex (Fig. $1 A$ ). These findings from conditional mutant brain are consistent with the previously observed loss of nuclear MLL1 protein in hematopoietic cells after exon 3 and 4 deletions (Jude et al., 2007). In addition, Camk-Cre ${ }^{+}$conditional mutants showed strong reduction of cortical Mll1 RNA when measured with exon $3+4$ spanning primers $\left(N=4\right.$ /group, $p<0.05 ; t_{(6)}=3.322, p<$ $0.05)$, while maintaining normal levels of expression for two related genes, Mll2 and Mll3 (Fig. 1A). However, cytoarchitecture and gross brain morphology was normal in Camk-Cre ${ }^{+}$conditional mutants (Fig. $1 A)$, which showed a mild $(\sim 10 \%)$ reduction in brain weight at postnatal month 3 (mutants $379 \pm 2$, controls $425 \pm 3 \mathrm{mg}, t_{(10)}=12.53 ; p<0.001$ ).

Given that H3K4 methylation landscapes in the neurons of human PFC are frequently dysregulated in cognitive and neurodevelopmental disease (Huang et al., 2007; Shulha et al., 2012; Shen et al., 2014), we wanted to find out whether conditional Mll1 deletion in the forebrain would compromise behaviors that are sensitive to PFC dysfunction, including spatial working memory (SWM) and anxiety (Dalley et al., 2004; Bi et al., 2013; O'Neill et al., 2013). For each behavioral test, we compared Camk2aCre ${ }^{+}, M_{l l} 1^{\text {flox }}$ flox conditional mutants to Camk2aCre ${ }^{-}$, Mll1 $1^{\text {flox/flox }}$ controls ( $N=8-10$ mice/genotype). We probed SWM in two different maze systems (T-maze and eight-arm radial maze). Young adult (10- to 12-week-old) conditional mutants showed severe SWM deficits compared with controls, as evidenced by an $\sim 2$-fold decrease in spontaneous T-maze alternations $\left(t_{(18)}=8.067, p<\right.$ 0.001 ) and $\sim 3$-fold increase in repeat entries ("errors") in the radial maze $\left(t_{(18)}=5.999, p<0.001\right.$; Fig. 1B). The Camk2aCre ${ }^{+}$, $M l l 1^{f l o x / f l o x}$ mice showed elevated levels of anxiety, with increased aversion to the bright compartment in the light-dark box test (latency first entry, $t_{(18)}=2.326, p<0.05$; crossings $t_{(18)}=4.448$, $p<0.001$ ) and decreased entries (post hoc after two-way mixed ANOVA; $\left.F_{(1,18)}=15.83, p<0.001\right)$ and reduced time spent in the (anxiogenic) center of the open field test $\left(F_{(1,18)}=41.5, p<\right.$ 0.001 ; Fig. $1 B$ ). Furthermore, mutant nest building was impaired $\left(t_{(6)}=3.656, p<0.05\right.$; Fig. $\left.1 B\right)$, a phenotype often encountered in mice with defective cognition or social behaviors (Moretti et al., 2005; Udagawa et al., 2013). However, locomotor coordination, measured by rotarod assay, was very similar between mutant and controls (Fig. 1B), which speaks against a generalized neurological dysfunction after conditional Mll1 deletion in forebrain neurons.

To explore the molecular alterations underlying impaired cognition and increased anxiety in Camk-Cre ${ }^{+} \mathrm{Mll1}^{\text {2lox/2lox }}$ mice, 
A

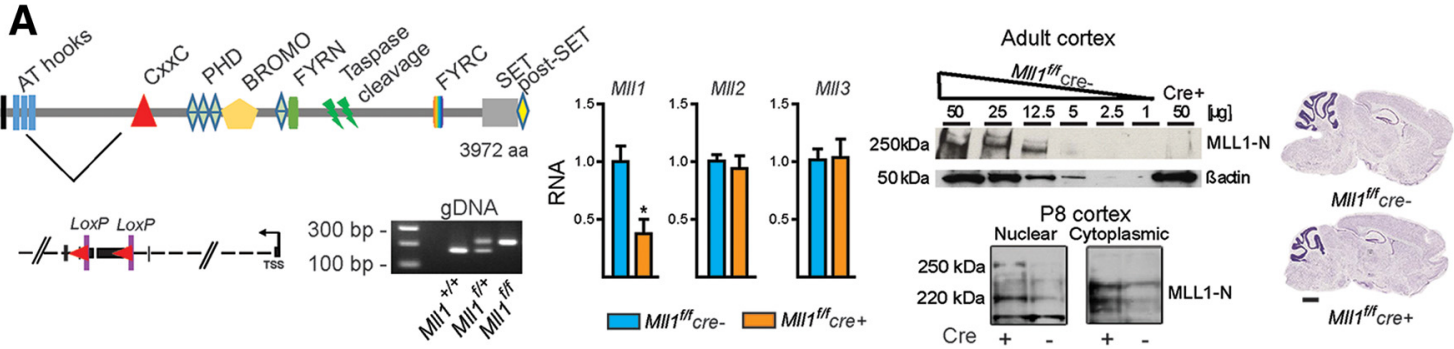

B

Working memory

T-Maze Radial Arm

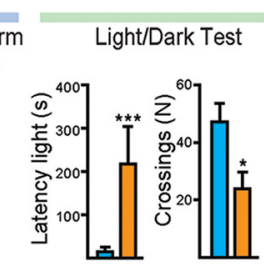

Anxiety
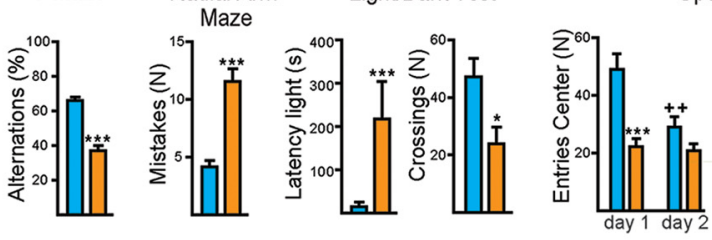

Open-field
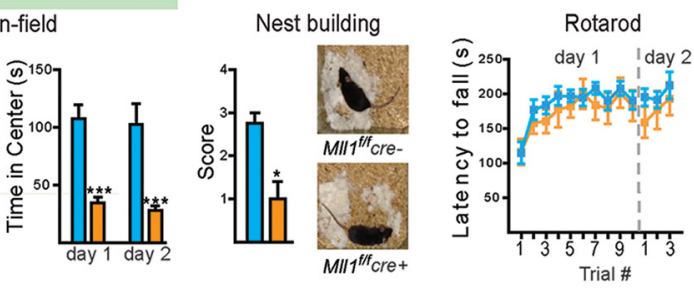

C

Frontal cortex transcriptome

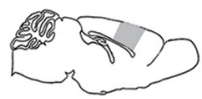

GO Categories
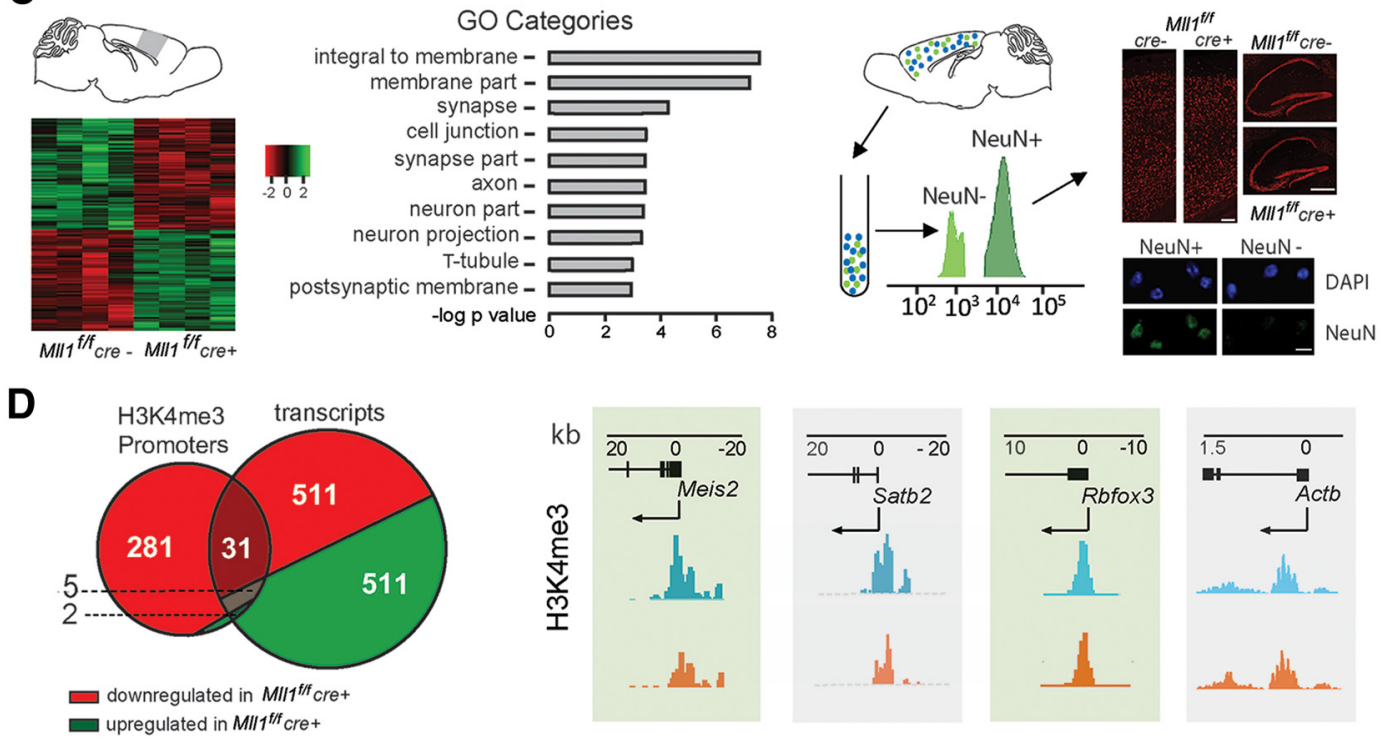

E

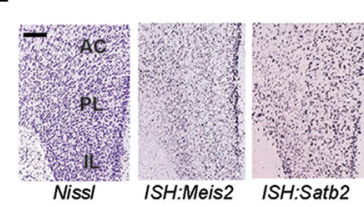

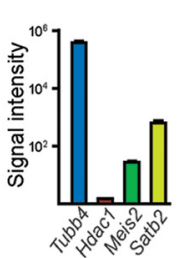
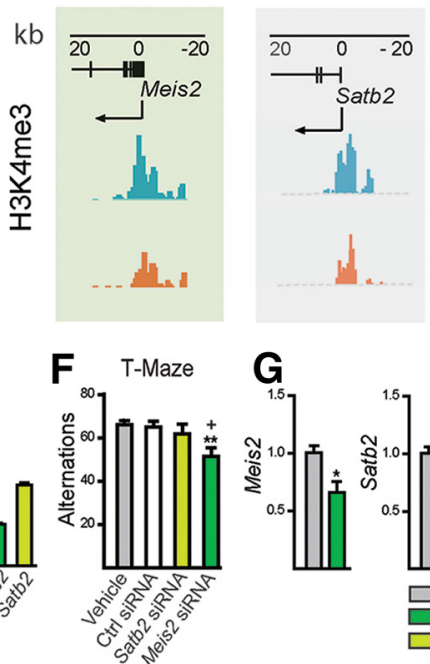

G

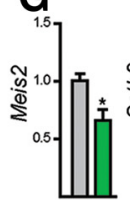

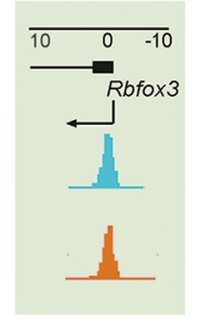

H

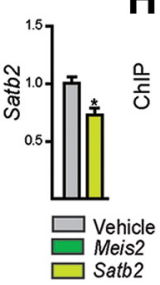

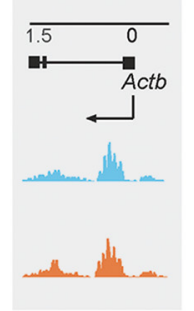

Meis2

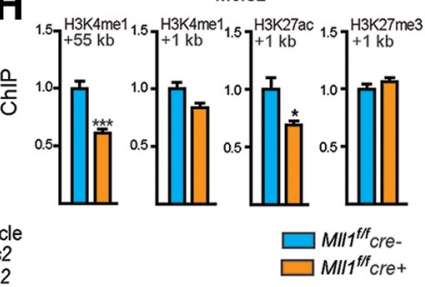

Figure 1. Neuron-specific MII1 deletion in forebrain ( $\boldsymbol{A}$; left) MLL1 protein including taspase autocleavage site and additional functional domains, position of loxP ( flox) sites flanking exons 3 and 4 for conditional deletion, and PCR-based genotype screen. Middle, RT-PCR-based quantification of MII1, MII2, and MII3 methyltransferase genes in Camk2a-Cre ${ }^{+}, M_{1 / 1}{ }^{f l o x}$ fflox and Camk2a-Cr${ }^{-}$, MIII $1^{\text {floxfflox }}$ cortex. Right, Immunoblots for MLL1 N-terminal fragment from adult and P8 lysates control and conditional mutant cortex. Note nuclear enrichment of $250 \mathrm{kDa}$ MLL1 protein in wild-type, and loss of $250 \mathrm{kDa}$ band in adult mutant. Nissl stainings of sagittal section of conditional mutant and control brains reveal no gross alterations. Scale bar, $1 \mathrm{~mm}$. B, Behavioral alterations in Camk2a-Cre ${ }^{+}$, MII ${ }^{\text {flox/flox }}$ mice (left to right): T-maze and radial maze to assay working memory, averaged across 4 days of testing. Note below chance-level alternations (T-maze) and increased repeat entries ("mistakes") in radial maze in mutants. Light- dark box to measure anxiety, showing latencies to first enter into light compartment and $N$ of crossings into light compartment over 10 min period. Open field assay, showing time spent in anxiogenic imaginary center square during a 15 min test period. Nest building scores were significantly impaired in Camk2a-Cre ${ }^{+}$, MIII floxfflox mice. Representative images of nests made by control animal and mutant during the full extent of one dark phase. Rotarod locomotor coordination during day 1 with sequential increases in rotation speed, and day 2 retest at highest speed (40 rpm). C, Neuronal epigenome and transcriptome alterations after conditional MII1 gene deletion. Left, Microarray-based transcriptome assessment on prefrontal tissue homogenate. Heat map from microarray of MII1-deficient mice and wild-type littermates ( $N=4 /$ group); red to green gradient depicting $\geq 2$-fold increase $\rightarrow \leq 2$-fold decrease. Bar graph shows enrichment for neuronal categories in Gene Ontology (G0) "Cellular Component" tree. Right, Sorted cortical neuronal nuclei tagged with NeuN + antibody, for H3K4me3 ChIP-seq. Representative fluorescence distribution shown for 1000 sorting events. Notice complete separation of $\mathrm{NeuN}^{+}$and NeuN ${ }^{-}$nuclei. Cortical and hippocampal sections show normal NeuN immunohistochemistry in conditional mutant. D. Venn diagram representing all annotated TSS with significantly decreased (red) or increased (green) H3K4me3 signal in Camk2a-Cre ${ }^{+}$, MIII flox/flox cortical neurons, compared with control. Note overwhelming portion (99\%) of H3K4me3 peak changes in mutant neurons are downward. Overlap with MII1-sensitive transcriptome includes 31 genes with decreases in H3K4me3 at TSS and of the corresponding transcript. Genome browser tracks for H3K4me3 landscapes in cortical neurons, 40 kb windows (Figure legend continues.) 
we profiled transcriptomes from the adult rostromedial cortex using Affymetrix Mouse Gene 1.0 ST microarrays. Altogether, 1092 probesets from 1022 genes showed altered expression in 4/4 mutants $(>1.2$-fold difference to controls, FDR-corrected $p<$ 0.05; Fig. $1 C$ ). In the pool of 1022 genes, an equal number of genes was either upregulated or downregulated, and there was a strong neuronal footprint with significant enrichment for many synapse-, axon-, and membrane-associated categories (FDR corrected $p<0.05$; Fig. $1 C$ ). Such broad changes in the cortical transcriptome, together with the aforementioned behavioral phenotypes, could indicate profound neuronal dysfunction in Mll1 mutant mice. To distinguish transcriptional dysregulation caused by Mll1 deficiency from secondary alterations in RNA levels, we sorted and separated (Mll1-deficient) neuronal nuclei from the (non-Mll1-deficient) non-neuronal nuclei of the conditional mutant cortex (Fig. 1C) for subsequent genome-scale $\mathrm{H} 3 \mathrm{~K} 4$ methylation profiling with single base pair resolution. We focused on the trimethylated mark, $\mathrm{H} 3 \mathrm{~K} 4 \mathrm{me} 3$, because this mark presents as sharp peaks surrounding gene-proximal promoters and TSSs (Guenther et al., 2007; Barrera et al., 2008). Furthermore, $\mathrm{H} 3 \mathrm{~K} 4 \mathrm{me} 3$ tends, on a genome-wide scale, to show stronger correlations with gene expression patterns compared with the more broadly distributed monomethylated and dimethylated forms (H3K4me1/2; Santos-Rosa et al., 2002; Eissenberg and Shilatifard, 2010). On a genome-wide scale, the H3K4me3 mark correlates with RNA polymerase II occupancy at sites of gene expression (Guenther et al., 2005), providing an additional layer of transcriptional regulation to facilitate or repress expression, depending on local chromatin context (Shilatifard, 2008, 2012). Notably, Mll1 deficiency in peripheral tissues leads to loss of $\mathrm{H} 3 \mathrm{~K} 4 \mathrm{me} 3$ at $<5 \%$ of all $\mathrm{H} 3 \mathrm{~K} 4 \mathrm{me} 3$-tagged promoters, of which only a subset shows deficits in levels of the corresponding gene transcripts (Wang et al., 2009; Denissov et al., 2014). Likewise, hippocampal pyramidal neurons with mutations in Mll2-a close Mll1 homolog among the SET-domain containing H3K4 methyltransferases-show expression changes for $<25$ transcripts (Kerimoglu et al., 2013). Therefore, we hypothesized that Mll1 deficiency in cortical neurons too will result in selective $\mathrm{H} 3 \mathrm{~K} 4 \mathrm{me} 3$ deficits at a very small subset of promoter-bound sequences, in conjunction with decreased levels of the corresponding $\mathrm{RNA}(\mathrm{s})$. Indeed, this is what we observed. Altogether 318 promoter-bound $\mathrm{H} 3 \mathrm{~K} 4 \mathrm{me} 3$ peaks were altered in mutant neurons $(N=4$ mice/group, $>1.5$-fold change, FDR-corrected $p<$ 0.05 ), of which $99 \%$ were decreased and $12 \%$ matched to a gene transcript with altered mRNA expression (31/38 downregulated; $\chi^{2}$ : df $(1)=10.57, p<0.01$; Fig. 1D). Among the 31 genes affected by a significant deficit in H3K4me3 in Mll1-deficient mutant cortical neurons, multiple neuropsychiatric susceptibility genes ranked among the most heavily affected as it pertains to decreased RNA and loss of H3K4me3, including the Meis2 homeobox transcription factor important for cortical and striatal

(Figure legend continued.) centered at TSS of Meis2 (chr2), and Satb2 (chr1) genes, and for comparison, 20 and $2 \mathrm{~kb}$ around Rbfox3 (encoding NeuN) and Actb. Note loss of H3K4me3 signal specifically at Meis2 and Satb2 in mutants (orange), compared with controls (blue). $\boldsymbol{E}$, Allen Brain Atlas screenshots (adult cortex), showing robust expression for Meis2 and Satb2 by in situ hybridization (ISH). Signal intensity on adult PFC microarray (C) comparing Meis2 and Satb2 expression relative to high (low) expressed $T u b b 4$ (Hdac 1 ). AC, anterior cingulate; PL, prelimbic; IL, infralimbic. $\boldsymbol{F}$, T-maze alternations ( $N=10-14 /$ group) and RNA knockdown ( $\mathbf{G} ; N=$ 4/group) after prefrontal injections of vehicle, control (UGGUUUACAUGUCGACUAA), Meis2 (CAUUCAUGCCCAAUAGUAU) or Satb2 (GGAUUAUUGUCAGAGAUAC) siRNA. H, H3K4me1, H3K27ac, and H3K27me3 ChIP-PCR at Meis2 as indicated. ${ }^{*},{ }^{* *}$, ${ }^{* *} p<0.05,0.01,0.001$.
Table 1. Genes with deficits in promoter-bound H3K4me3 in MII1-deficient cortex ( $>1.5$-fold from control) and significant decrease in expression

\begin{tabular}{|c|c|c|c|c|c|}
\hline $\mathrm{Chr}$ & Start & End & Nearest TSS (kb) & Transcript (FC) & H3K4me3 (FC) \\
\hline chr1 & 57025981 & 57026244 & Satb2 $(+2065)$ & -1.71 & -7.25 \\
\hline chr1 & 57026819 & 57027293 & Satb2 $(+1122)$ & -1.71 & -13.25 \\
\hline chr2 & 115888047 & 115888297 & Meis2 $(+2622)$ & -1.58 & -8.42 \\
\hline chr15 & 91020306 & 91020562 & $\operatorname{Abcd} 2(+1804)$ & -1.51 & -4.58 \\
\hline chr13 & 97695894 & 97696191 & Gent4 (+ 1399) & -1.41 & -3.66 \\
\hline chr17 & 66279021 & 66279342 & $\operatorname{Scn} 1 a(-288)$ & -1.38 & -2.11 \\
\hline chr2 & 85037656 & 85037917 & $\operatorname{Lrrc55}(-931)$ & -1.36 & -4.08 \\
\hline chr12 & 100137950 & 100138190 & $E m / 5(+1624)$ & -1.35 & -2.32 \\
\hline chr19 & 7006971 & 7007555 & Kcnk4 (+ 1742) & -1.32 & -10.11 \\
\hline chr18 & 7002288 & 7002752 & $M k x(+2257)$ & -1.32 & -4.53 \\
\hline chr4 & 124664023 & 124664531 & Rspo1 (+603) & -1.32 & -3.17 \\
\hline chr19 & 24781899 & 24782101 & Zmat4 (+1867) & -1.31 & -1.7 \\
\hline chr11 & 120095519 & 120095896 & Bahcc1 (+ 1447) & -1.30 & -17.07 \\
\hline chr11 & 120094771 & 120095017 & Bahcc1 (+633) & -1.30 & -12.68 \\
\hline chr14 & 67256884 & 67257100 & Adra1a $(+2897)$ & -1.30 & -1.7 \\
\hline chr2 & 73112178 & 73112456 & $\operatorname{Sp9}(+2334)$ & -1.26 & -2.35 \\
\hline chr16 & 31934529 & 31934729 & Pigz $(+692)$ & -1.26 & -1.37 \\
\hline chr1 & 171675597 & 171676009 & $\operatorname{Rgs} 4(+1970)$ & -1.24 & -5.08 \\
\hline chr5 & 98612210 & 98612575 & $\operatorname{Prdm} 8(+2505)$ & -1.23 & -8.54 \\
\hline chr16 & 21206592 & 21206866 & Ephb3 $(+1861)$ & -1.23 & -2.44 \\
\hline chr11 & 98903864 & 98904163 & Igfbp4 $(+1440)$ & -1.23 & -1.52 \\
\hline chr9 & 91259187 & 91259499 & Zic1 (+1294) & -1.23 & -1.19 \\
\hline chr15 & 59482113 & 59482725 & Trib1 $(+2210)$ & -1.22 & -10.27 \\
\hline chr1 & 179377749 & 179377979 & $2 f p 238(+3072)$ & -1.22 & -5.69 \\
\hline chr1 & 179377256 & 179377470 & $2 f p 238(+2571)$ & -1.22 & -3.88 \\
\hline chr1 & 179375682 & 179375983 & Zfp238(+1041) & -1.22 & -3.41 \\
\hline chr6 & 88676263 & 88676784 & $\operatorname{Mgll}(+2118)$ & -1.22 & -2.56 \\
\hline chr11 & 109333561 & 109334055 & $\begin{array}{l}\operatorname{Arsg}(-880) \\
\text { Slc16a6 }\end{array}$ & -1.22 & -3.16 \\
\hline chr10 & 60638412 & 60638862 & Tbata $(+3925)$ & -1.21 & -3.31 \\
\hline chr13 & 114453356 & 114453745 & $H s p b 3(+333)$ & -1.21 & -2.15 \\
\hline chr11 & 43647614 & 43647814 & Adra1b $(+2120)$ & -1.21 & -1.97 \\
\hline chr13 & 114452232 & 114452561 & $H s p b 3(+1487)$ & -1.21 & -1.82 \\
\hline chr1 & 185858744 & 185859005 & $\begin{array}{l}\text { 1700056E22Rik } \\
\text { (-998), Dusp10 (+535) }\end{array}$ & -1.21 & -1.74 \\
\hline chr13 & 60638905 & 60639229 & Tbata $(+4355)$ & -1.21 & -1.68 \\
\hline chr1 & 19094413 & 19094928 & Tcfap2d (+1568) & -1.21 & -2.94 \\
\hline
\end{tabular}

development (Takahashi et al., 2008; Larsen et al., 2010) and Special AT-rich sequence binding protein 2 (Satb2) essential for cortical projection neuron differentiation (Britanova et al., 2008; Fig. 1D, Table 1). Importantly, Meis 2 and Satb2 expression levels are maintained at high levels across all neuronal layers of the adult PFC (Fig. 1E), which would suggest that these genes, in addition to their critical role during early neurodevelopment, could remain important for neuronal health and function even in fully matured cortex. To examine this, we subjected adult, threemonth-old wild-type (C57BL/6J) mice to intracranial injections of siRNA to knockdown Meis2 and Satb2 transcripts in the PFC, then measured, 3 days after surgery, SWM by T-maze. There was significant spatial working memory impairment in animals treated with Meis2 siRNA, but not Satb2 or additional control siRNAs (one-way ANOVA, $F_{(3,41)}=4.33, p<0.01$; Fig. $1 F$ ). The decrease in spatial working memory after Meis 2 knockdown was milder compared with the impaired maze performance of Mll1 conditional mutants (Fig. 1, compare $B, F$ ). Knockdown efficiencies were monitored by qRT-PCR-based Meis2 and Satb2 RNA quantification in PFC, confirming significant downregulation in Meis2 (or Satb2, respectively) in siRNA-injected animals (Meis2, $t_{(4)}=3.231, p<0.05$; Satb2, $t_{(6)}=3.295, p<0.05$; Fig. $\left.1 G\right)$. This Meis2 siRNA-mediated downregulation, $\sim 30-40 \%$ (Fig. $1 G$ ), was only slightly less than the $\sim 50 \%$ decrease in expression ob- 


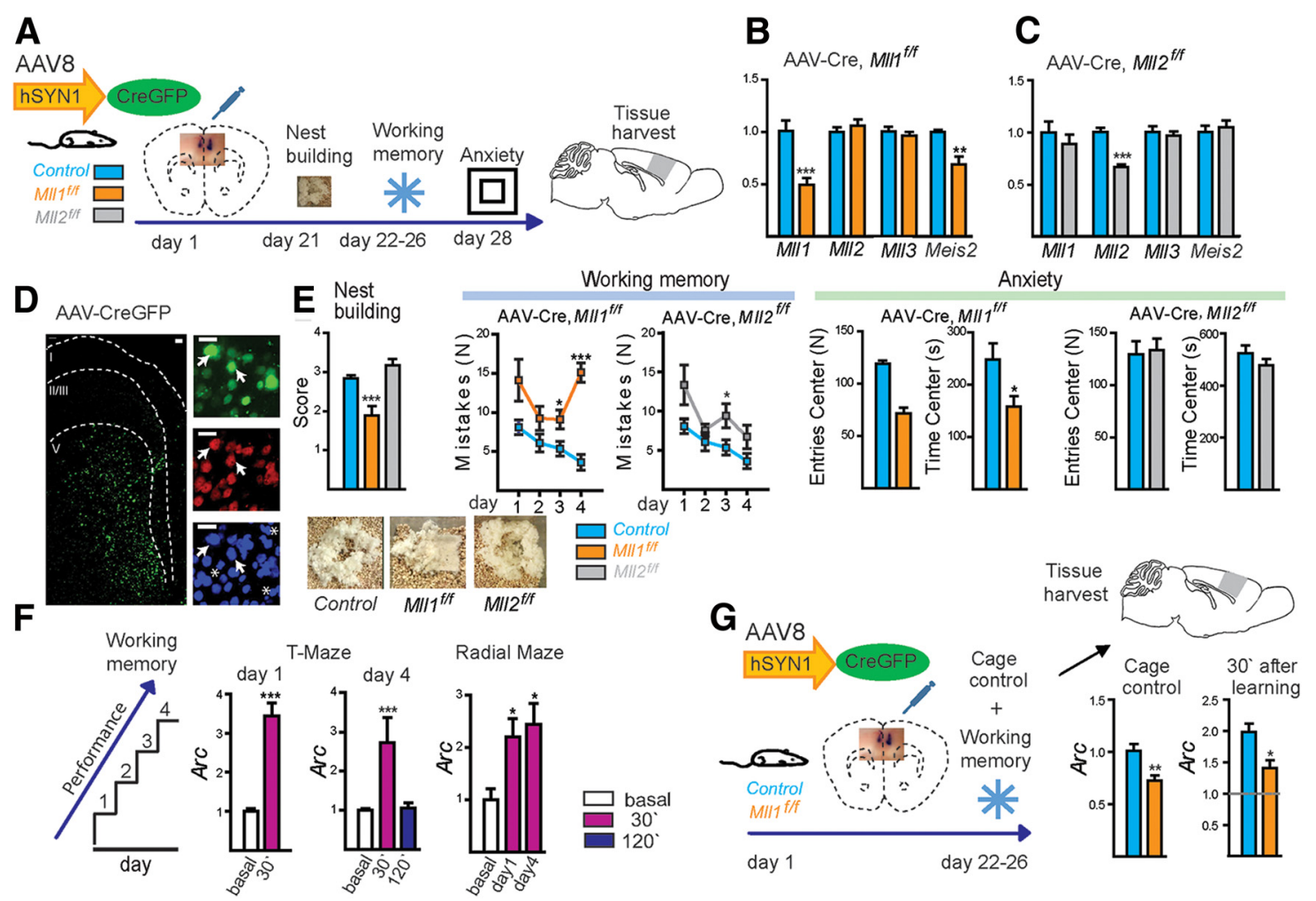

Figure 2. MII1 and MII2 deletion in adult PFC neurons. A, Time line. MII1 $7^{\text {floxfflox }}$ and $M I I 2^{\text {flox/flox }}$ and wild-type $\left(M I 11^{+/+}, M I 12^{+/+}\right)$controls receive bilateral一photomicrograph showing dye-marked PFC injections_-AAV8 vector for Synapsin 1 promoter-driven expression of CreGFP fusion protein, followed by behavioral assays. B, C, Summary of qRT-PCR from $1 \mathrm{to} 2 \mathrm{~mm}$ tissue blocks

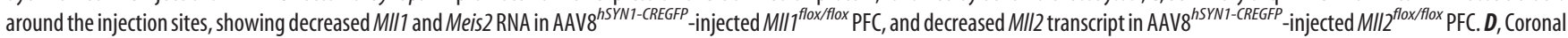
sections from AAV8 ${ }^{\text {hSYN1-CREGFP }}$-injected PFC, CreGFP green, NeuN immunostain red, and DAPI counterstain blue. Arrows (stars), NeuN ${ }^{+}$(NeuN ${ }^{-}$) nuclei. Scale bars: Left, $100 \mu \mathrm{m}$; Right, $50 \mu \mathrm{m}$.

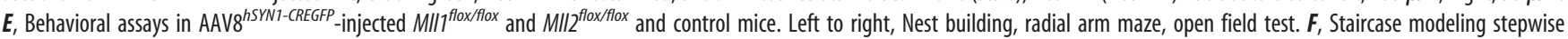
improvement of spatial working memory-related performance in maze assays. Bar graphs summarizing transient waves of Arc expression in PFC, with 3- to 4-fold increase in expression at 30 min but not 120 min after task performance. G, Decreased Arc expression at baseline and 30 min after day 4 of radial maze task in AAV8 ${ }^{\text {hSYN1-CREGFP }}$-injected PFC (gray line, baseline Arc RNA in wild-type). $N=5-7$ animals/time point and genotype. ${ }^{*},{ }^{* *}, * * * 0005,0.01,0.001$.

served in qRT-PCR assays from conditional mutant PFC $\left(\right.$ Camk2aCre $^{+}$, Mll flox/flox $^{\text {flo }} 0.534 \pm 0.088$; Camk2aCre ${ }^{-}$, Mll $^{\text {flox/flox }}$ $1 \pm 0.156)$. These findings, suggest that Mll1 plays an essential role for working memory by regulating a small set of target genes in adult PFC neurons, including the Meis2 transcription factor.

MLL1 protein upregulates in addition to the trimethyl form, $\mathrm{H} 3 \mathrm{~K} 4 \mathrm{me} 3$, monomethylated and dimethylated $\mathrm{H} 3 \mathrm{~K} 4$ (H3K4me1/H3K4me2; Del Rizzo and Trievel, 2011). The H3K4me1 and H3K4me2 marks are broadly enriched at many "active" enhancers and promoters (Creyghton et al., 2010; Zhou et al., 2011). Furthermore, MLL1-associated proteins are thought to recruit histone acetyltransferases to promoter sequences, and $\mathrm{H} 3 \mathrm{~K} 4$ methylation is often coregulated with histone acetylation (Huang et al., 2007; Tie et al., 2014). Therefore, we conducted ChIP-PCR experiments on PFC from Camk2aCre ${ }^{+}, \mathrm{Mll1}^{\text {flox/flox }}$ and control mice, to measure $\mathrm{H} 3 \mathrm{~K} 4 \mathrm{me} 1$ and $\mathrm{H} 3 \mathrm{~K} 27 \mathrm{ac}$, and the repressive mark, $\mathrm{H} 3 \mathrm{~K} 27 \mathrm{me} 3$, at Meis2 regulatory sequences. These marks are often enriched at promoters, enhancers, and other cis-regulatory sequences involved in transcriptional regulation in various tissues, including brain (Zhu et al., 2013; Bharadwaj et al., 2014). Indeed, Meis2 promoter sequences sharply enriched with the H3K4me3 mark showed a significant deficit in $\mathrm{H} 3 \mathrm{~K} 27$ acetylation $\left(t_{(11)}=2.731, p<0.05\right.$; Fig. $\left.1 H\right)$. In contrast, $\mathrm{H} 3 \mathrm{~K} 4 \mathrm{mel}$ levels at the same sequences showed a subtle nonsignificant decrease, which did not survive a two-tailed $t$ test $\left(t_{(11)}=\right.$ $2.182, p=0.052$ ). However, a more robust $\mathrm{H} 3 \mathrm{~K} 4 \mathrm{me} 1$ deficit was observed at sequences $55,8 \mathrm{~kb}$ from the TSS $\left(t_{(11)}=5.071, p<\right.$
0.001), which in wild-type cortex showed strong H3K4me1 enrichment, according to reference epigenomic maps from mouse cerebral cortex (Shen et al., 2012). In contrast, no significant changes were found for the repressive mark, H3K27me3, at the site of the Meis2 promoter. Our ChIP-PCR studies suggest that loss of Mll1 could affect $\mathrm{H} 3 \mathrm{~K} 4$ monomethylation, dimethylation, and trimethylation at selected sequences and additional histone modifications, including acetylation (Fig. $1 H$ ).

Having shown that loss Mll1 in postnatal brain compromises the animal's ability to show normal performance in tasks sensitive to PFC dysfunction, including SWM and anxiety, we asked whether some of the behavioral phenotypes after postnatal, forebrain wide Mll1 deletion could be recapitulated after regionspecific gene ablation in adult PFC. Therefore, to test whether Mll1 deletion in mature brain results in a neurological phenotype, we bilaterally injected into rostromedial cortex/ventral PFC (Dalley et al., 2004) of P80-P100 mice AAV for neuron-specific expression of CreGFP fusion protein (AAV8 ${ }^{h S Y N 1-C r e G F P}$; Fig. $2 A, D)$. Mammalian genomes harbor at least $11 \mathrm{H} 3 \mathrm{~K} 4$-specific methyltransferase genes (Black et al., 2012). Therefore, to find out whether any behavioral phenotypes after gene deletion in PFC neurons are specific for Mll1, we conducted parallel studies in mice homozygous for the Mll1 ortholog, Mll2/Kmt $2 b^{\text {flox/flox }}$ (Kerimoglu et al., 2013; Ladopoulos et al., 2013). The PFC of Mll1 $1^{\text {flox/flox }}$ and Mll $2^{\text {flox/flox }}$ mice injected with AAV8 ${ }^{\text {hSYN1-CreGFP }}$ showed a significant $\sim 30-60 \%$ loss of Mll1 $\left(t_{(7)}=4.239, p<\right.$ $0.001)$ or, respectively, Mll2 RNA $\left(t_{(9)}=6.466, p<0.001\right.$; Fig. 
$2 B, C)$, with CreGFP expression specific to prefrontal neurons (Fig. 2D). Furthermore, Meis2 RNA was decreased by $\sim 40 \%$ in Mll1 $1^{\text {flox/flox }}$ PFC $\left(t_{(7)}=3.522, p<0.01\right.$; Fig. $\left.2 B\right)$ but not in Mll $2^{\text {flox/flox }}$ PFC injected with AAV8 ${ }^{h S Y N 1-C r e G F P}$ (Fig. 2C). Importantly, AAV8 ${ }^{h S Y N 1-C r e G F P}$-injected Mll1 $1^{\text {flox/flox }}$ mice showed, compared with AAV8 ${ }^{h S Y N 1-C r e G F P}$-injected wild-type controls, robust deficits in nest building $\left(t_{(33)}=3.780, p<0.001\right)$ and radial arm maze/working memory performance as assessed by 4 consecutive days of testing (two-way mixed ANOVA, effect by genotype, $\left.F_{(1,29)}=15.58, p<0.001\right)$ in conjunction with elevated levels of anxiety in the open field test $\left(N\right.$ center entries, $t_{(16)}=5.288, p<$ 0.01 ; Fig. $2 E$ ). In contrast, behavioral performances were not significantly altered in AAV8 ${ }^{h S Y N 1-C r e G F P}$-injected $M l l 2^{\text {flox/flox }}$ mice, compared with AAV8 ${ }^{h S Y N 1-C r e G F P}$-injected wild-type controls, with the notable exception of a mild impairment in working memory (two-way mixed ANOVA, effect by genotype, $F_{(1,21)}=$ 7.04, $p<0.05$; Fig. 2E).

Having shown that Mll1 in mature PFC neurons is essential for normal cognition and behavior, we wanted to explore some of the underlying molecular mechanisms. We noted that our wildtype mice, consistent with previous studies (Kolata et al., 2008; Udagawa et al., 2013; Line et al., 2014), showed stepwise improvement in working memory performance when tested over multiple consecutive days, including a declining error rate in the radial arm maze assays across the $4 \mathrm{~d}$ test period (Fig. $2 E$ ). Interestingly, expression of Arc/Arg3.1, encoding activity-regulated cytoskeletonassociated protein, an early response gene and critical regulator of synaptic plasticity (Shepherd and Bear, 2011), was among the list of 511 genes (Fig. 1D) significantly downregulated at baseline $(-1.48$-fold, FDR corrected $p<0.01)$ in the array-based transcriptome assessment of the Mll1-deficient PFC (Fig. 1D). We therefore hypothesized that Arc expression in PFC is dynamically regulated in mice exposed to a cognitive challenge such as radial maze-related working memory. Indeed, this is what we observed in C57BL/6J wild-type mice, with Arc transcript showing a transient, $\sim 4$-fold increase at $30 \mathrm{~min}$ after task performance in the T-maze and radial maze paradigms, followed by return to baseline at $120 \mathrm{~min}(N=5-9$ wild-type C57BL6 animals per time point; one-way ANOVA; T-maze $F_{(2,15)}=12.85, p<0.001$; radial arm maze $F_{(2,12)}=5.34, p<0.05$; Fig. $\left.2 F\right)$. These transient waves of $A r c$ expression were present at the first and the fourth (last) day of testing (Fig. 2F), indicating that Arc induction in the PFC is not subject to desensitization after repeated maze exposures. To further explore Arc regulation in Mll1-deficient PFC, we first confirmed downregulated Arc expression in PFC at baseline, using a second batch of mutant and control mice for RT-PCR-based RNA quantifications (mean \pm SEM,

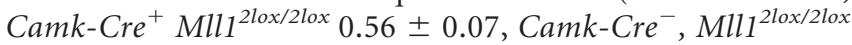
$\left.1.00 \pm 0.13, t_{(6)}=2.92, p<0.05\right)$. We then confirmed decreased $A r c$ expression in AAV8 ${ }^{h S Y N 1-C r e G F P}$-injected $M l l 1^{2 l o x / 2 l o x}$ mice at baseline $\left(t_{(9)}=2.38, p<0.01\right)$. In contrast to AAV8 ${ }^{h S Y N 1-C r e G F P}$-injected wild-type animals, AAV8 ${ }^{h S Y N 1-C r e G F P}$ injected $M l l 1^{2 l o x / 2 l o x}$ mice only showed a minimal increase in Arc expression when assessed $30 \mathrm{~min}$ after radial arm maze training $\left(t_{(10)}=3.015, p<0.05\right.$; Fig. $\left.2 G\right)$.

Having shown that Mll1 ablation profoundly affects measures of behavioral and molecular (Arc) plasticity, we next explored synaptic signaling in mutant and control neurons. Of note, disrupted short-term plasticity (STP) in the PFC is associated with cognitive dysfunction, including impairments in working memory, generally defined as the short-term retention of information in the preparation of forthcoming action (Constantinidis and Wang, 2004; Gordon, 2011; Fénelon et al., 2013). To examine
PFC STP in Mll1-deficient PFC, we recorded from PFC layer V pyramidal neurons, the major output relay of the cortex. The frequencies of AMPA receptor-mediated mEPSC were significantly higher in conditional mutant Camk2aCre ${ }^{+}, \mathrm{Mll}^{\text {flox/flox }}$ neurons $\left(t_{(21)}=3.005, p<0.01\right)$ while amplitudes were indistinguishable from controls $\left(t_{(21)}=0.563, p=0.6\right.$; Fig. $\left.3 A, B\right)$. These results suggest a higher probability of presynaptic transmitter release $(P r)$, or an increase in the number of functional synapses in the Mll1-deficient PFC.

To assess whether there is an increase in the presynaptic neurotransmitter release efficiency, we studied evoked synaptic transmission by stimulating the superficial cortical layers (II/III), major sites of afferent fibers that converge on the apical dendrites of layer $\mathrm{V}$ pyramidal neurons. We compared the magnitude of facilitation that occurs in response to paired-pulse stimulation, a reliable measure of changes in $\operatorname{Pr}$ (Zucker and Regehr, 2002), especially at low probability synapses. PPR, a reliable measure of changes in $\operatorname{Pr}$ (Zucker and Regehr, 2002), especially at low probability synapses, was significantly lower at all interpulse intervals tested between 20 and $100 \mathrm{~ms}$ in Mll1 mutant mice $\left(20 \mathrm{~ms}, t_{(15)}=\right.$ $2.468, p<0.05 ; 50 \mathrm{~ms}, t_{(17)}=3.384, p<0.01 ; 100 \mathrm{~ms}, t_{(17)}=$ 2.301, $p<0.05 ; 150 \mathrm{~ms}, t_{(10)}=0.269, p=0.3$; Fig. $\left.3 C, D\right)$, suggesting an increased $P r$ of glutamate release at mutant terminals. To further probe presynaptic function, we examined synaptic responses under current clamp to high-frequency train stimulation, which allows assessment of presynaptic depression and sustainment of postsynaptic depolarization at physiological firing frequencies. We applied a 10-pulse train at physiological frequencies (Funahashi et al., 1989; Sawaguchi et al., 1990; Miller et al., 1996) followed by a recovery test pulse (Fig. 3E). At $10 \mathrm{~Hz}$, wild-type neurons displayed stable EPSPs during repetitive stimulations with a modest temporal summation of postsynaptic depolarization. In contrast, Mll1-deficient neurons showed rapidly depressing EPSPs without temporal summation (Fig. 3E,F). At $20 \mathrm{~Hz}$, both wild-type and mutant neurons displayed an initial facilitation followed by a phase of depression of EPSPs, but mutants showed a smaller facilitation and a faster and more complete synaptic depression than those in wild-type neurons. The decrease in EPSP amplitude in response to successive pulses during a train of stimuli reflects presynaptic vesicle depletion, and more depletion occurs as frequency increases and correlates with higher $\operatorname{Pr}$ (Zucker and Regehr, 2002). These results support the notion that excitatory inputs onto PFC neurons have a higher presynaptic release probability in Camk2aCre ${ }^{+}, \mathrm{Mll}^{\text {flox/flox }}$ mutant mice.

Synaptic augmentation (lasting up to $10 \mathrm{~s}$ ) and PTP (lasting longer than $30 \mathrm{~s}$ and up to a few minutes; Zucker and Regehr, 2002), are two forms of STP that can be induced by highfrequency titanic stimulation at many synapses, including the PFC (Hempel et al., 2000; Wang et al., 2006). Lasting facilitation of EPSPs in control mice was evident from the EPSP response to the recovery test stimulus delivered $1 \mathrm{~s}$ after the 10-pulse stimulation train, suggesting the presence of STP at these PFC synapses (Fig. 3E). To further examine whether augmentation and PTP were impaired in Mll1-deficient PFC, we monitored posttetanic EPSPs for up to $100 \mathrm{~s}$ (Fig. 3G). We observed substantial synaptic augmentation (Fig. $3 G$ ) and PTP, lasting for at least $90 \mathrm{~s}$ (Fig. $3 \mathrm{H}$ ) in control neurons. In contrast, mutant neurons failed to show sustained synaptic augmentation and PTP $\left(t_{(10-13)}=2.32-2.81\right.$; Fig. $\left.3 H\right)$ and these results strongly point to defective synaptic signaling, including impaired STP, in the Mll1-deficient PFC. 
A
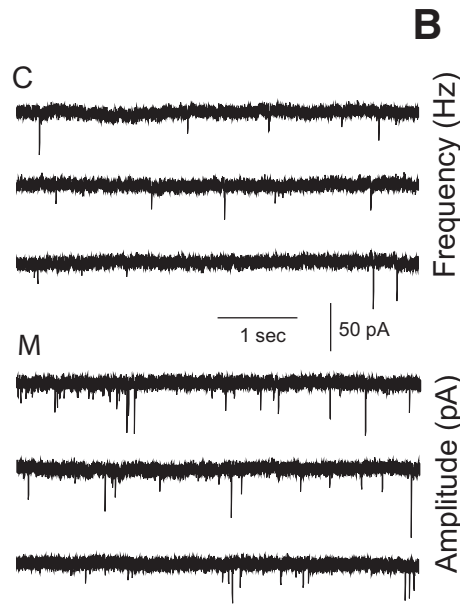

E
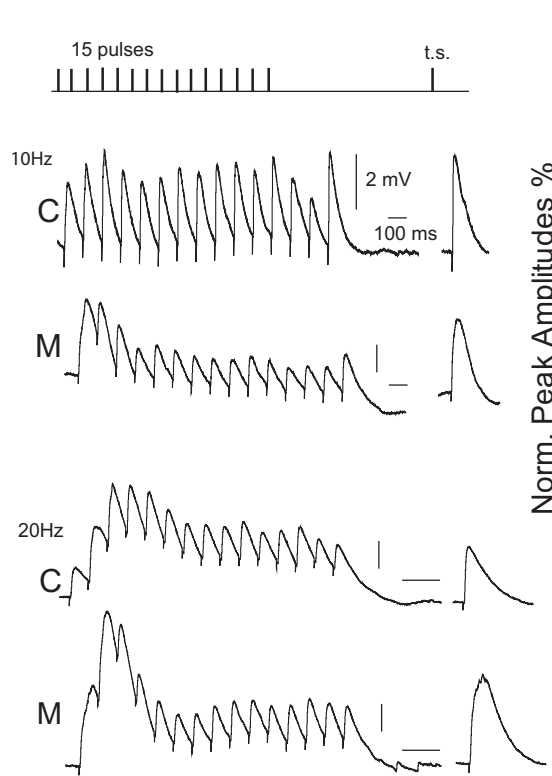

$\mathbf{F}$

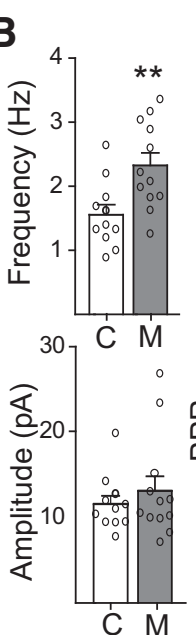

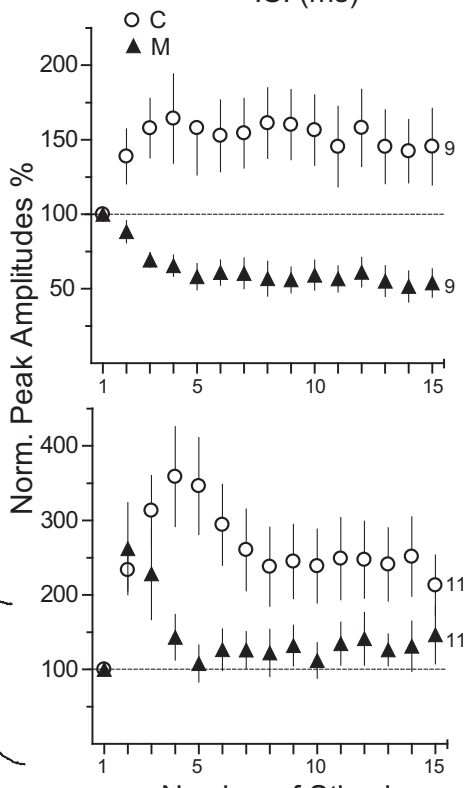

C<smiles>[CH]C</smiles><smiles>C1CCCC1</smiles>
$\mathrm{M}$

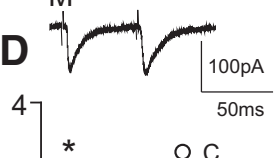

$\triangle \mathrm{M}$
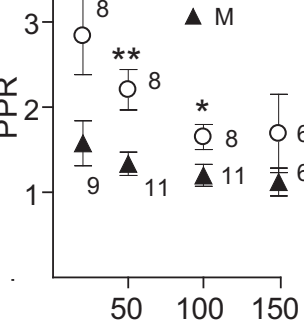

ISI (ms)

O C

Number of Stimulus
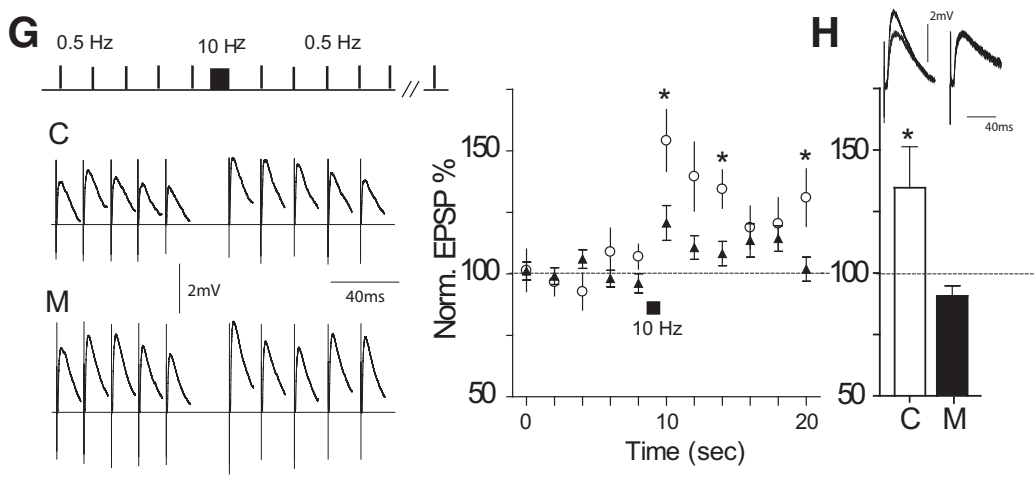

Figure 3. Enhanced presynaptic neurotransmitter release, impaired temporal summation, and STP in MII1-deficient mice. $\boldsymbol{A}, \boldsymbol{B}$, Representative mEPSC recordings from control (C) and conditional Camk2a-Cre ${ }^{+}, M I 17^{\text {flox fllox }}$ mutant (M) PFC neurons, including quantification of frequency and amplitude. C, Representative recordings of PPR at interpulse intervals of 20 and $50 \mathrm{~ms}$ from wild-type and mutant neurons. D, PPRs at various interpulse intervals $(\boldsymbol{E})$. Representative traces of evoked EPSPs in response to a 15-pulse stimulus train at $10 \mathrm{~Hz}$ (upper) or $20 \mathrm{~Hz}$ (lower) followed by a recovery test pulse recorded from control (C) and mutant (M) neurons. Note that recovery testing responses remained facilitated compared with the first EPSP in the train. $\boldsymbol{F}$, Summary of normalized EPSP amplitudes (to the peak of first EPSP) versus stimulus sequence during the train. Note substantial temporal summations at the end of both 10 and $20 \mathrm{~Hz}$ stimulus train in wild-type, but not mutant neurons. $\mathbf{G}$, Absence of synaptic augmentation in $\mathrm{MIl} 1$ mutant neurons. Augmentation was induced by a 15 -pulse tetanus at $10 \mathrm{~Hz}$. Single-action potential-evoked testing responses before and after induction was measured at $0.5 \mathrm{~Hz}$. $\mathbf{H}$, Impaired PTP in mutant (M) neurons. The five EPSPs recorded between 90 and $100 \mathrm{~s}$ post-tetanus were averaged to compute PTP. ${ }^{*},{ }^{* *} p<0.05,0.01$.

\section{Discussion}

The present study provides a deep and integrative exploration of Mll1-dependent regulation of $\mathrm{H} 3 \mathrm{~K} 4$ methylation in $\mathrm{PFC}$ neurons. Region- and cell type-specific Mll1 gene deletions, including Cremediated recombination in adult PFC neurons, were associated with broad alterations in complex behaviors, elevated levels of anxiety, defective nest building (which in mice is often linked to alterations in social cognition), and a marked impairment in spatial working memory. These behavioral alterations were not associated with gross neurological dysfunction or defects in locomotor coordination, and rotarod performance was indistinguishable from controls. However, Mll1 apparently is essential for orderly synaptic activity in mature neurons, because the Mll1-deficient PFC layer V pyramidal neurons of the present study were severely affected by defective STP, which is critical for delayed period persistent activity underlying working memory (Miller and Cohen, 2001; Seamans et al., 2001). Furthermore, we observed a loss of the stepwise improvement in maze/spatial working memory task performances after prefrontal Mll1 ablation. Notably, this loss of behavioral plasticity was accompanied by a corresponding loss in molecular plasticity in the Mll1-deficient PFC, as evidenced by altered expression of the activity-regulated cytoskeleton-associated protein Arc, a key regulator for synaptic plasticity in prefrontal cortex (Krueger et al., 2011; Ren et al., 2014) and other brain regions (Shepherd and Bear, 2011). In the present study, levels of $\operatorname{Arc}$ RNA were transiently increased in wildtype PFC, for at least $30 \mathrm{~min}$, after the animals had been in the T-maze and radial arm maze. In striking contrast, Arc expression in Mll1-deficient PFC was downregulated at baseline, with minimal induction after maze training.

The neuronal phenotypes after Mll1 gene deletion, including (1) the impairments in cognition and complex behaviors; (2) the severe defects in short-term synaptic plasticity of PFC projection neurons; and (3) the marked attenuation of task-related transient waves of Arc expression, when taken together, convincingly show that Mll1 is essential for maintenance of health and function in mature cortical neurons. This is further reflected by a broadly dysregulated cortical transcriptome, with $\sim 1000$ genes, many of which assigned to neuronal function and synaptic signaling by Gene Ontology (Fig. $1 C$ ), showing mostly a subtle, $\sim 1.2$-fold change in expression. These alterations 
are likely to underlie the severe STP defects in prefrontal projection neurons as reported here. These transcriptional alterations could result from dysregulated H3K4 methylation and other epigenetic marks such as $\mathrm{H} 3 \mathrm{~K} 27 \mathrm{ac}$, or alternatively, reflect secondary mechanisms operating downstream of the primary defect. Of note, our combined epigenome/transcriptome analyses of Mll1 mutant and wild-type cortex revealed only a small subset of 31 genes affected by a more robust ( $>1.5$-fold) deficit of H3K4me3 in conjunction with decreased levels of the corresponding gene transcript (Fig. 1D, Table 1). These included several neurodevelopmental susceptibility genes including Meis2 (Takahashi et al., 2008; Larsen et al., 2010), a transcription factor expressed at high levels in mature PFC neurons (Fig. $1 E$ ). It is surprising that until now, Meis2 functions had not been studied in adult brain. In the present study, small RNA-mediated Meis2 knockdown in adult PFC led to impairments in working memory and cognition (Fig. $1 F)$. Our results, when taken together, suggest that mature prefrontal neurons critically depend on maintenance of Mll1regulated $\mathrm{H} 3 \mathrm{~K} 4$ methylation at a small subset of genes with an essential role in cognition and emotion. The findings presented here broadly resonate with studies in peripheral tissues, reporting that Mll1 deficiency leads to loss of $\mathrm{H} 3 \mathrm{~K} 4 \mathrm{me} 3$ at $<5 \%$ of all $\mathrm{H} 3 \mathrm{~K} 4 \mathrm{me} 3$-tagged promoters in the genome, of which only a fraction is associated with deficits in levels of the corresponding gene transcripts (Wang et al., 2009; Denissov et al., 2014). Likewise, hippocampal pyramidal neurons lacking the Mll1 ortholog Mll2 show expression changes for $<25$ transcripts (Kerimoglu et al., 2013). In each of these studies and other studies involving Mll1 or Mll2 mutant mice (Ernst et al., 2004; Huang et al., 2007; Jude et al., 2007; Kim et al., 2007), the Mll1 (or Mll2)-depleted cells showed very specific defects in growth, differentiation, or function, which would suggest that Mll1, Mll2, and probably additional genes encoding H3K4-specific lysine methyltransferases (KMT) each play a nonredundant role, by controlling a very limited subset of critical genes that differ according to H3K4 KMT, and cell type and tissue. Our study provides evidence that this working model applies to the mature brain. After Mll1 and Mll2 were ablated in adult PFC neurons via AAV8 ${ }^{h S Y N 1-C r e G F P}$, mice showed impaired cognition, a phenotype that was more robust in Mll1-deficient PFC. This was associated with downregulated expression of Meis2, which according to the present study is a critical driver gene for the working memory deficits after Mll1 but not Mll2 ablation.

Notably, both Mll1 and Mll2 - two closely related H3K4 KMTs sharing an almost identical set of functional domains (Long et al., 2013) — are highly expressed in adult PFC and other brain regions (Lein et al., 2007), and are thought to require additional subunits to attain maximal methyltransferase activity toward H3K4, with the "WRAD" (WDR5, RbBP5, ASH2L, and DPY30) as prototype example for the MLL-associated protein complex (Del Rizzo and Trievel, 2011; Ernst and Vakoc, 2012). Therefore, small molecule drugs interfering with MLL-WRAD binding and catalytic activity (Karatas et al., 2013; Cao et al., 2014) bear promising potential as novel treatment avenues for psychiatric disease, given the emerging role of $\mathrm{H} 3 \mathrm{~K} 4$-specific KMTs, including MLL1, as powerful epigenomic regulator of cognition and emotion.

\section{References}

Aguilar-Valles A, Vaissière T, Griggs EM, Mikaelsson MA, Takács IF, Young EJ, Rumbaugh G, Miller CA (2014) Methamphetamine-associated memory is regulated by a writer and an eraser of permissive histone methylation. Biol Psychiatry 76:57-65. CrossRef Medline

Akbarian S, Rios M, Liu RJ, Gold SJ, Fong HF, Zeiler S, Coppola V, Tessarollo
L, Jones KR, Nestler EJ, Aghajanian GK, Jaenisch R (2002) Brainderived neurotrophic factor is essential for opiate-induced plasticity of noradrenergic neurons. J Neurosci 22:4153-4162. Medline

Audic S, Claverie JM (1997) The significance of digital gene expression profiles. Genome Res 7:986-995. Medline

Bai G, Cheung I, Shulha HP, Coelho JE, Li P, Dong X, Jakovcevski M, Wang Y, Grigorenko A, Jiang Y, Hoss A, Patel K, Zheng M, Rogaev E, Myers RH, Weng Z, Akbarian S, Chen JF (2015) Epigenetic dysregulation of hairy and enhancer of split 4 (HES4) is associated with striatal degeneration in postmortem Huntington brains. Hum Mol Genet 24:1441-1456. CrossRef Medline

Barrera LO, Li Z, Smith AD, Arden KC, Cavenee WK, Zhang MQ, Green RD, Ren B (2008) Genome-wide mapping and analysis of active promoters in mouse embryonic stem cells and adult organs. Genome Res 18:46-59. CrossRef Medline

Bharadwaj R, Peter CJ, Jiang Y, Roussos P, Vogel-Ciernia A, Shen EY, Mitchell AC, Mao W, Whittle C, Dincer A, Jakovcevski M, Pothula V, Rasmussen TP, Giakoumaki SG, Bitsios P, Sherif A, Gardner PD, Ernst P, Ghose S, Sklar P, et al. (2014) Conserved higher-order chromatin regulates NMDA receptor gene expression and cognition. Neuron 84:997-1008. CrossRef Medline

Bi LL, Wang J, Luo ZY, Chen SP, Geng F, Chen YH, Li SJ, Yuan CH, Lin S, Gao TM (2013) Enhanced excitability in the infralimbic cortex produces anxiety-like behaviors. Neuropharmacology 72:148-156. CrossRef Medline

Black JC, Van Rechem C, Whetstine JR (2012) Histone lysine methylation dynamics: establishment, regulation, and biological impact. Mol Cell 48: 491-507. CrossRef Medline

Britanova O, de Juan Romero C, Cheung A, Kwan KY, Schwark M, Gyorgy A, Vogel T, Akopov S, Mitkovski M, Agoston D, Sestan N, Molnár Z, Tarabykin V (2008) Satb2 is a postmitotic determinant for upper-layer neuron specification in the neocortex. Neuron 57:378-392. CrossRef Medline

Cao F, Townsend EC, Karatas H, Xu J, Li L, Lee S, Liu L, Chen Y, Ouillette P, Zhu J, Hess JL, Atadja P, Lei M, Qin ZS, Malek S, Wang S, Dou Y (2014) Targeting MLL1 H3K4 methyltransferase activity in mixed-lineage leukemia. Mol Cell 53:247-261. CrossRef Medline

Cheung I, Shulha HP, Jiang Y, Matevossian A, Wang J, Weng Z, Akbarian S (2010) Developmental regulation and individual differences of neuronal H3K4me3 epigenomes in the prefrontal cortex. Proc Natl Acad Sci U S A 107:8824-8829. CrossRef Medline

Constantinidis C, Wang XJ (2004) A neural circuit basis for spatial working memory. Neuroscientist 10:553-565. CrossRef Medline

Creyghton MP, Cheng AW, Welstead GG, Kooistra T, Carey BW, Steine EJ, Hanna J, Lodato MA, Frampton GM, Sharp PA, Boyer LA, Young RA, Jaenisch R (2010) Histone H3K27ac separates active from poised enhancers and predicts developmental state. Proc Natl Acad Sci U S A 107: 21931-21936. CrossRef Medline

Dalley JW, Cardinal RN, Robbins TW (2004) Prefrontal executive and cognitive functions in rodents: neural and neurochemical substrates. Neurosci Biobehav Rev 28:771-784. CrossRef Medline

Deacon RM (2006) Assessing nest building in mice. Nat Protoc 1:11171119. CrossRef Medline

Del Rizzo PA, Trievel RC (2011) Substrate and product specificities of SET domain methyltransferases. Epigenetics 6:1059-1067. CrossRef Medline

Denissov S, Hofemeister H, Marks H, Kranz A, Ciotta G, Singh S, Anastassiadis K, Stunnenberg HG, Stewart AF (2014) Mll2 is required for H3K4 trimethylation on bivalent promoters in embryonic stem cells, whereas Mll1 is redundant. Development 141:526-537. CrossRef Medline

Eissenberg JC, Shilatifard A (2010) Histone H3 lysine 4 (H3K4) methylation in development and differentiation. Dev Biol 339:240-249. CrossRef Medline

Ernst P, Vakoc CR (2012) WRAD: enabler of the SET1-family of H3K4 methyltransferases. Brief Funct Genomics 11:217-226. CrossRef Medline

Ernst P, Fisher JK, Avery W, Wade S, Foy D, Korsmeyer SJ (2004) Definitive hematopoiesis requires the mixed-lineage leukemia gene. Dev Cell 6:437443. CrossRef Medline

Fénelon K, Xu B, Lai CS, Mukai J, Markx S, Stark KL, Hsu PK, Gan WB, Fischbach GD, MacDermott AB, Karayiorgou M, Gogos JA (2013) The pattern of cortical dysfunction in a mouse model of a schizophreniarelated microdeletion. J Neurosci 33:14825-14839. CrossRef Medline

Fischer A (2014) Targeting histone-modifications in Alzheimer's disease. 
What is the evidence that this is a promising therapeutic avenue? Neuropharmacology 80:95-102. CrossRef Medline

Funahashi S, Bruce CJ, Goldman-Rakic PS (1989) Mnemonic coding of visual space in the monkey's dorsolateral prefrontal cortex. J Neurophysiol 61:331-349. Medline

Glaser S, Lubitz S, Loveland KL, Ohbo K, Robb L, Schwenk F, Seibler J, Roellig D, Kranz A, Anastassiadis K, Stewart AF (2009) The histone 3 lysine 4 methyltransferase, Mll2, is only required briefly in development and spermatogenesis. Epigenetics Chromatin 2:5. CrossRef Medline

Gordon JA (2011) Oscillations and hippocampal-prefrontal synchrony. Curr Opin Neurobiol 21:486-491. CrossRef Medline

Guenther MG, Jenner RG, Chevalier B, Nakamura T, Croce CM, Canaani E, Young RA (2005) Global and Hox-specific roles for the MLL1 methyltransferase. Proc Natl Acad Sci U S A 102:8603-8608. CrossRef Medline

Guenther MG, Levine SS, Boyer LA, Jaenisch R, Young RA (2007) A chromatin landmark and transcription initiation at most promoters in human cells. Cell 130:77-88. CrossRef Medline

Gupta S, Kim SY, Artis S, Molfese DL, Schumacher A, Sweatt JD, Paylor RE, Lubin FD (2010) Histone methylation regulates memory formation. J Neurosci 30:3589-3599. CrossRef Medline

Han Y, Han D, Yan Z, Boyd-Kirkup JD, Green CD, Khaitovich P, Han JD (2012) Stress-associated H3K4 methylation accumulates during postnatal development and aging of rhesus macaque brain. Aging Cell 11:10551064. CrossRef Medline

Hempel CM, Hartman KH, Wang XJ, Turrigiano GG, Nelson SB (2000) Multiple forms of short-term plasticity at excitatory synapses in rat medial prefrontal cortex. J Neurophysiol 83:3031-3041. Medline

Houston I, Peter CJ, Mitchell A, Straubhaar J, Rogaev E, Akbarian S (2013) Epigenetics in the human brain. Neuropsychopharmacology 38:183-197. CrossRef Medline

Hsieh JJ, Ernst P, Erdjument-Bromage H, Tempst P, Korsmeyer SJ (2003) Proteolytic cleavage of MLL generates a complex of N- and C-terminal fragments that confers protein stability and subnuclear localization. Mol Cell Biol 23:186-194. CrossRef Medline

Huang HS, Matevossian A, Whittle C, Kim SY, Schumacher A, Baker SP, Akbarian S (2007) Prefrontal dysfunction in schizophrenia involves mixed-lineage leukemia 1-regulated histone methylation at GABAergic gene promoters. J Neurosci 27:11254-11262. CrossRef Medline

Jude CD, Climer L, Xu D, Artinger E, Fisher JK, Ernst P (2007) Unique and independent roles for MLL in adult hematopoietic stem cells and progenitors. Cell Stem Cell 1:324-337. CrossRef Medline

Karatas H, Townsend EC, Cao F, Chen Y, Bernard D, Liu L, Lei M, Dou Y, Wang S (2013) High-affinity, small-molecule peptidomimetic inhibitors of MLL1/WDR5 protein-protein interaction. J Am Chem Soc 135: 669-682. CrossRef Medline

Kauffmann A, Gentleman R, Huber W (2009) arrayQualityMetrics-a bioconductor package for quality assessment of microarray data. Bioinformatics 25:415-416. CrossRef Medline

Kerimoglu C, Agis-Balboa RC, Kranz A, Stilling R, Bahari-Javan S, BenitoGaragorri E, Halder R, Burkhardt S, Stewart AF, Fischer A (2013) Histone-methyltransferase MLL2 (KMT2B) is required for memory formation in mice. J Neurosci 33:3452-3464. CrossRef Medline

Kim SY, Levenson JM, Korsmeyer S, Sweatt JD, Schumacher A (2007) Developmental regulation of Eed complex composition governs a switch in global histone modification in brain. J Biol Chem 282:9962-9972. CrossRef Medline

Kolata S, Wu J, Light K, Schachner M, Matzel LD (2008) Impaired working memory duration but normal learning abilities found in mice that are conditionally deficient in the close homolog of L1. J Neurosci 28:1350513510. CrossRef Medline

Krueger DD, Osterweil EK, Chen SP, Tye LD, Bear MF (2011) Cognitive dysfunction and prefrontal synaptic abnormalities in a mouse model of fragile X syndrome. Proc Natl Acad Sci U S A 108:2587-2592. CrossRef Medline

Ladopoulos V, Hofemeister H, Hoogenkamp M, Riggs AD, Stewart AF, Bonifer C (2013) The histone methyltransferase KMT2B is required for RNA polymerase II association and protection from DNA methylation at the MagohB CpG island promoter. Mol Cell Biol 33:1383-1393. CrossRef Medline

Langmead B, Trapnell C, Pop M, Salzberg SL (2009) Ultrafast and memoryefficient alignment of short DNA sequences to the human genome. Genome Biol 10:R25. CrossRef Medline
Larsen KB, Lutterodt MC, Laursen H, Graem N, Pakkenberg B, Møllgard K, Møller M (2010) Spatiotemporal distribution of PAX6 and MEIS2 expression and total cell numbers in the ganglionic eminence in the early developing human forebrain. Dev Neurosci 32:149-162. CrossRef Medline

Lein ES, Hawrylycz MJ, Ao N, Ayres M, Bensinger A, Bernard A, Boe AF, Boguski MS, Brockway KS, Byrnes EJ, Chen L, Chen L, Chen TM, Chin MC, Chong J, Crook BE, Czaplinska A, Dang CN, Datta S, Dee NR, et al. (2007) Genome-wide atlas of gene expression in the adult mouse brain. Nature 445:168-176. CrossRef Medline

Line SJ, Barkus C, Rawlings N, Jennings K, McHugh S, Sharp T, Bannerman DM (2014) Reduced sensitivity to both positive and negative reinforcement in mice overexpressing the 5-hydroxytryptamine transporter. Eur J Neurosci 40:3735-3745. CrossRef Medline

Long HK, Blackledge NP, Klose RJ (2013) ZF-CxxC domain-containing proteins, $\mathrm{CpG}$ islands and the chromatin connection. Biochem Soc Trans 41:727-740. CrossRef Medline

Lopez-Atalaya JP, Barco A (2014) Can changes in histone acetylation contribute to memory formation? Trends Genet 30:529-539. CrossRef Medline

Matevossian A, Akbarian S (2008) A chromatin assay for human brain tissue. J Vis Exp 21:717. CrossRef Medline

Miller EK, Cohen JD (2001) An integrative theory of prefrontal cortex function. Annu Rev Neurosci 24:167-202. CrossRef Medline

Miller EK, Erickson CA, Desimone R (1996) Neural mechanisms of visual working memory in prefrontal cortex of the macaque. J Neurosci 16 : 5154-5167. Medline

Moretti P, Bouwknecht JA, Teague R, Paylor R, Zoghbi HY (2005) Abnormalities of social interactions and home-cage behavior in a mouse model of Rett syndrome. Hum Mol Genet 14:205-220. CrossRef Medline

Nakajima H, Kubo T, Semi Y, Itakura M, Kuwamura M, Izawa T, Azuma YT, Takeuchi T (2012) A rapid, targeted, neuron-selective, in vivo knockdown following a single intracerebroventricular injection of a novel chemically modified siRNA in the adult rat brain. J Biotechnol 157:326333. CrossRef Medline

O'Neill PK, Gordon JA, Sigurdsson T (2013) Theta oscillations in the medial prefrontal cortex are modulated by spatial working memory and synchronize with the hippocampus through its ventral subregion. J Neurosci 33:14211-14224. CrossRef Medline

Pruitt KD, Tatusova T, Brown GR, Maglott DR (2012) NCBI Reference Sequences (RefSeq): current status, new features and genome annotation policy. Nucleic Acids Res 40:D130-D135. CrossRef Medline

Ren M, Cao V, Ye Y, Manji HK, Wang KH (2014) Arc regulates experiencedependent persistent firing patterns in frontal cortex. J Neurosci 34:65836595. CrossRef Medline

Santos-Rosa H, Schneider R, Bannister AJ, Sherriff J, Bernstein BE, Emre NC, Schreiber SL, Mellor J, Kouzarides T (2002) Active genes are trimethylated at K4 of histone H3. Nature 419:407-411. CrossRef Medline

Sawaguchi T, Matsumura M, Kubota K (1990) Effects of dopamine antagonists on neuronal activity related to a delayed response task in monkey prefrontal cortex. J Neurophysiol 63:1401-1412. Medline

Schoch H, Abel T (2014) Transcriptional co-repressors and memory storage. Neuropharmacology 80:53-60. CrossRef Medline

Seamans JK, Durstewitz D, Christie BR, Stevens CF, Sejnowski TJ (2001) Dopamine D1/D5 receptor modulation of excitatory synaptic inputs to layer V prefrontal cortex neurons. Proc Natl Acad Sci U S A 98:301-306. CrossRef Medline

Shao Z, Zhang Y, Yuan GC, Orkin SH, Waxman DJ (2012) MAnorm: a robust model for quantitative comparison of ChIP-Seq data sets. Genome Biol 13:R16. CrossRef Medline

Shen E, Shulha H, Weng Z, Akbarian S (2014) Regulation of histone H3K4 methylation in brain development and disease. Philos Trans R Soc Lond B Biol Sci 369:20130514. CrossRef Medline

Shen Y, Yue F, McCleary DF, Ye Z, Edsall L, Kuan S, Wagner U, Dixon J, Lee L, Lobanenkov VV, Ren B (2012) A map of the cis-regulatory sequences in the mouse genome. Nature 488:116-120. CrossRef Medline

Shepherd JD, Bear MF (2011) New views of Arc, a master regulator of synaptic plasticity. Nat Neurosci 14:279-284. CrossRef Medline

Shilatifard A (2008) Molecular implementation and physiological roles for histone H3 lysine 4 (H3K4) methylation. Curr Opin Cell Biol 20:341-348. CrossRef Medline

Shilatifard A (2012) The COMPASS family of histone H3K4 methylases: 
mechanisms of regulation in development and disease pathogenesis. Annu Rev Biochem 81:65-95. CrossRef Medline

Shulha HP, Cheung I, Whittle C, Wang J, Virgil D, Lin CL, Guo Y, Lessard A, Akbarian S, Weng Z (2012) Epigenetic signatures of autism: trimethylated H3K4 landscapes in prefrontal neurons. Arch Gen Psychiatry 69: 314-324. CrossRef Medline

Takahashi K, Liu FC, Oishi T, Mori T, Higo N, Hayashi M, Hirokawa K, Takahashi H (2008) Expression of FOXP2 in the developing monkey forebrain: comparison with the expression of the genes FOXP1, PBX3, and MEIS2. J Comp Neurol 509:180-189. CrossRef Medline

Takata A, Xu B, Ionita-Laza I, Roos JL, Gogos JA, Karayiorgou M (2014) Loss-of-function variants in schizophrenia risk and SETD1A as a candidate susceptibility gene. Neuron 82:773-780. CrossRef Medline

Tie F, Banerjee R, Saiakhova AR, Howard B, Monteith KE, Scacheri PC, Cosgrove MS, Harte PJ (2014) Trithorax monomethylates histone $\mathrm{H} 3 \mathrm{~K} 4$ and interacts directly with CBP to promote H3K27 acetylation and antagonize Polycomb silencing. Development 141:1129-1139. CrossRef Medline

Udagawa T, Farny NG, Jakovcevski M, Kaphzan H, Alarcon JM, Anilkumar S, Ivshina M, Hurt JA, Nagaoka K, Nalavadi VC, Lorenz LJ, Bassell GJ, Akbarian S, Chattarji S, Klann E, Richter JD (2013) Genetic and acute CPEB1 depletion ameliorate fragile X pathophysiology. Nat Med 19: 1473-1477. CrossRef Medline

Wang P, Lin C, Smith ER, Guo H, Sanderson BW, Wu M, Gogol M, Alexander T, Seidel C, Wiedemann LM, Ge K, Krumlauf R, Shilatifard A (2009)
Global analysis of H3K4 methylation defines MLL family member targets and points to a role for MLL1-mediated H3K4 methylation in the regulation of transcriptional initiation by RNA polymerase II. Mol Cell Biol 29:6074-6085. CrossRef Medline

Wang Y, Markram H, Goodman PH, Berger TK, Ma J, Goldman-Rakic PS (2006) Heterogeneity in the pyramidal network of the medial prefrontal cortex. Nat Neurosci 9:534-542. CrossRef Medline

Xu TX, Sotnikova TD, Liang C, Zhang J, Jung JU, Spealman RD, Gainetdinov RR, Yao WD (2009) Hyperdopaminergic tone erodes prefrontal longterm potential via a D2 receptor-operated protein phosphatase gate. J Neurosci 29:14086-14099. CrossRef Medline

Zhang Y, Liu T, Meyer CA, Eeckhoute J, Johnson DS, Bernstein BE, Nusbaum C, Myers RM, Brown M, Li W, Liu XS (2008) Model-based analysis of ChIP-Seq (MACS). Genome Biol 9:R137. CrossRef Medline

Zhou VW, Goren A, Bernstein BE (2011) Charting histone modifications and the functional organization of mammalian genomes. Nat Rev Genet 12:7-18. CrossRef Medline

Zhu J, Adli M, Zou JY, Verstappen G, Coyne M, Zhang X, Durham T, Miri M, Deshpande V, De Jager PL, Bennett DA, Houmard JA, Muoio DM, Onder TT, Camahort R, Cowan CA, Meissner A, Epstein CB, Shoresh N, Bernstein BE (2013) Genome-wide chromatin state transitions associated with developmental and environmental cues. Cell 152:642-654. CrossRef Medline

Zucker RS, Regehr WG (2002) Short-term synaptic plasticity. Annu Rev Physiol 64:355-405. CrossRef Medline 